Pablo Fernández 
The CIIF, International Center for Financial Research, is an interdisciplinary center with an international outlook and a focus on teaching and research in finance. It was created at the beginning of 1992 to channel the financial research interests of a multidisciplinary group of professors at IESE Business School and has established itself as a nucleus of study within the School's activities.

Ten years on, our chief objectives remain the same:

- Find answers to the questions that confront the owners and managers of finance companies and the financial directors of all kinds of companies in the performance of their duties

- Develop new tools for financial management

- Study in depth the changes that occur in the market and their effects on the financial dimension of business activity

All of these activities are programmed and carried out with the support of our sponsoring companies. Apart from providing vital financial assistance, our sponsors also help to define the Center's research projects, ensuring their practical relevance.

The companies in question, to which we reiterate our thanks, are:

Aena, A.T. Kearney, Caja Madrid, Fundación Ramón Areces, Grupo Endesa, Royal Bank of Scotland and Unión Fenosa.

http://www.iese.edu/ciif/ 


\title{
BETAS USED BY PROFESSORS: A SURVEY WITH 2,500 ANSWERS
}

\author{
Pablo Fernández ${ }^{1}$
}

\section{Abstract}

We report 2,510 answers from professors from 65 countries and 934 institutions. 1,791 respondents use betas, but 107 of them do not justify the betas they use.

97.3\% of the professors who justify the betas use regressions, webs, databases, textbooks or papers (the paper specifies which ones), although many of them state that calculated betas "are poorly measured and have many problems".

Only $0.9 \%$ of the professors justify the beta using exclusively personal judgment (named qualitative, common sense, intuitive, and logical magnitude betas by different professors).

The paper includes interesting comments from 160 professors.

We all admit that different investors may have different expected cash flows, but many of us affirm that the required return should be equal for everybody: That is a kind of schizophrenic approach to valuation. Most professors teach that the expected cash flows should be computed using common sense and good judgment about the company, its industry, the national economies... However, many professors teach a formula to calculate the discount rate (instead of again using common sense).

JEL Classification: G12, G31, M21

Keywords: beta, historical beta, calculated beta, common sense.

\footnotetext{
${ }^{1}$ Professor, Financial Management, PricewaterhouseCoopers Chair of Finance, IESE
}

Note: I am very grateful to the professors that answered this survey and to Maria Oleaga for improving earlier versions of this paper. Vicente J. Bermejo and Laura Parga provided excellent research assistance. 


\section{BETAS USED BY PROFESSORS: A SURVEY WITH 2,500 ANSWERS}

\section{Betas used by professors}

We sent a short email (see Exhibit 1) during the third week of April 2009 to about 8,000 email addresses of finance and economics professors obtained from previous correspondence, papers, and universities' websites. We asked about the Beta that "we, professors, use to calculate the required return to equity." We also asked how the number was justified.

By May 12, 2009, we had received 2,510 responses from professors ${ }^{1}$ from 65 countries. Of these 2,510 answers, 1,791 respondents used betas (see Table 1). 107 of these professors do not justify the betas that they use and the rest $(1,684)$ justify the betas.

Of the 1,684 professors who justify the betas that they use,

- $\quad 1,639(97.3 \%)$ justify the beta that they use with regressions, webs, databases, textbooks or papers.

- $15(0.9 \%)$ justify the beta using ONLY personal judgment (named qualitative betas, common sense betas, intuitive betas, logical magnitude betas and own judgment betas by different professors). 6 of them are in the United States, 6 in Spain, 1 in Austria, 1 in Australia and 1 in the Netherlands.

Exhibit 2 shows the main results of the survey by country.

\footnotetext{
${ }^{1}$ I also received answers from companies, banks and investment banks. I will analyse them in a separate document.
} 
Table 1

Main results of the survey

\begin{tabular}{|c|c|c|c|c|c|c|c|c|c|}
\hline & & $\begin{array}{l}\text { United } \\
\text { States }\end{array}$ & Europe & Asia & $\begin{array}{l}\text { Australia } \\
\text { and New } \\
\text { Zealand }\end{array}$ & Canada & $\begin{array}{r}\text { America } \\
\text { (ex United } \\
\text { States and } \\
\text { Canada) }\end{array}$ & Africa & TOTAL \\
\hline 1 & Number of answers & 1,340 & 748 & 170 & 94 & 80 & 66 & 12 & 2,510 \\
\hline 2 & Different countries & 1 & 26 & 20 & 2 & 1 & 11 & 4 & 65 \\
\hline 3 & Different institutions & 443 & 299 & 92 & 28 & 31 & 35 & 6 & 934 \\
\hline
\end{tabular}

\begin{tabular}{|l|l|r|r|r|r|r|r|r|r|}
\hline 4 & $\begin{array}{l}\text { Do not use betas, but use } \\
\text { Required return to equity }\end{array}$ & 87 & 43 & 5 & 9 & 2 & 3 & 2 & 151 \\
\hline 5 & Use betas & 995 & 478 & 138 & 60 & 58 & 53 & 9 & $\mathbf{1 , 7 9 1}$ \\
\hline 6 & Do not justify the betas & 62 & 26 & 11 & 3 & 4 & 0 & 1 & $\mathbf{1 0 7}$ \\
\hline
\end{tabular}

Justify the betas with:

\begin{tabular}{|c|c|c|c|c|c|c|c|c|c|}
\hline 7 & Regressions & 669 & 344 & 104 & 44 & 48 & 39 & 5 & 1,253 \\
\hline 8 & Webs and databases & 461 & 167 & 42 & 23 & 23 & 41 & 4 & 761 \\
\hline 9 & Textbooks or papers & 298 & 153 & 36 & 18 & 19 & 26 & 5 & 555 \\
\hline 10 & Cases & 12 & 4 & 0 & 0 & 0 & 0 & 0 & 16 \\
\hline 11 & Common sense, judgment... & 12 & 12 & 0 & 1 & 0 & 1 & 0 & 26 \\
\hline 12 & Other & 18 & 74 & 28 & 8 & 4 & 5 & 2 & 139 \\
\hline 13 & $\begin{array}{l}\text { Regressions, webs, databases, } \\
\text { textbooks or papers }\end{array}$ & 922 & 426 & 123 & 55 & 52 & 53 & 8 & 1,639 \\
\hline 14 & $\begin{array}{l}\text { Use ONLY Common sense, } \\
\text { judgment... }\end{array}$ & 6 & 8 & 0 & 1 & 0 & 0 & 0 & 15 \\
\hline
\end{tabular}

Do not use betas because

\begin{tabular}{|l|l|r|r|r|r|r|r|r|r|}
\hline 15 & Teach accounting or economics & 79 & 68 & 13 & 11 & 8 & 4 & 183 \\
\hline 16 & Teach basic finance & 47 & 27 & 3 & 4 & 3 & 1 & 85 \\
\hline 17 & CAPM is useless & 46 & 29 & 4 & 3 & 3 & 1 & 86 \\
\hline 18 & Do not provide a reason for it & 86 & 103 & 7 & 7 & 6 & 4 & 1 & 214 \\
\hline
\end{tabular}

Comments from professors who justify betas with regressions, webs, databases, textbooks or papers:

\begin{tabular}{|r|r|}
\hline I use calculated betas, but I always reference the articles that explain the problems with beta as well & 117 \\
\hline If one does not use beta then what is there? & 45 \\
\hline It is poorly measured, but no substitution so far. There are no better alternatives & 18 \\
\hline I use betas... but I use all metrics that are available & 80 \\
\hline I do not use betas, but I teach their use & 16 \\
\hline The model has received a Nobel Prize in Economics and while not perfect is used extensively in practice & 13 \\
\hline
\end{tabular}

Table 2 contains the most frequent comments of the professors who use "OTHER" justification for the betas. Table 3 contains the references (books and articles) cited by professors for justifying the use of calculated betas or the magnitude of the betas that they use. Table 4 contains the webs and databases cited by some of the 761 professors that use them. 
Table 2

Comments of the professors who reported "OTHER" justification of the betas

Annual report of firms that calculate EVA

Betas derived from options prices

Damodaran's bottom-up approach ${ }^{2}$

Beta's applied by official regulators

SWAG analysis (scientific wild-ass guess)
Bond premium model

Fundamentals

Hedge ratios

Sovereign risk

Continuous time finance
Fundamental beta ${ }^{3}$

Downside Beta

Implied beta

Total beta ${ }^{4}$

3-factor model

\section{Table 3}

Textbooks or papers cited by the professors for justifying the use of betas

\begin{tabular}{|c|c|c|c|c|}
\hline $\begin{array}{l}\text { Fama and French } \mathbf{7 3} \\
\text { Brealey et al. } \mathbf{4 1} \\
\text { Damodaran } \mathbf{4 1} \\
\text { Ross et al. } \mathbf{3 5} \\
\text { lbbotson } \mathbf{3 3} \\
\text { Sharpe } \mathbf{3 0} \\
\text { Bodie et al. } 19 \\
\text { Berk et al. } \mathbf{1 6} \\
\text { Brigham et al. } \mathbf{1 3} \\
\text { Lintner } \mathbf{1 1} \\
\text { Copeland et al. } \mathbf{1 0} \\
\text { Campbell } \mathbf{1 0} \\
\text { Elton and Gruber } \mathbf{9} \\
\text { Fernández } \mathbf{9} \\
\text { Dimson et al. } \mathbf{8} \\
\text { Graham and Harvey } \mathbf{8} \\
\text { Markowitz } \mathbf{8} \\
\text { Cochrane } \mathbf{6} \\
\text { Koller et al. } \mathbf{6}\end{array}$ & $\begin{array}{l}\text { Bruner } \mathbf{5} \\
\text { Carhart } \mathbf{5} \\
\text { Higgins } \mathbf{4} \\
\text { Grinblatt and Titman } \mathbf{4} \\
\text { Treynor } \mathbf{4} \\
\text { Gitman } \mathbf{3} \\
\text { Hull } \mathbf{3} \\
\text { Mossin } \mathbf{3} \\
\text { Blume } \mathbf{2} \\
\text { Brennan } \mathbf{2} \\
\text { Brown and Warner } \mathbf{2} \\
\text { Huang and Litzemberger } \mathbf{2} \\
\text { Jensen } \mathbf{2} \\
\text { Kaplan } \mathbf{2} \\
\text { Smith and Kiholm-Smith } \mathbf{2} \\
\text { Los } \mathbf{2} \\
\text { Marín and Rubio } \mathbf{2} \\
\text { Mascarenas } \mathbf{2} \\
\text { Palepu and Healy } \mathbf{2}\end{array}$ & 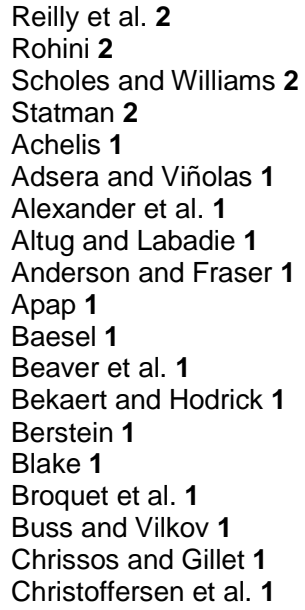 & $\begin{array}{l}\text { Comer et al. } 1 \\
\text { Cunningham } 1 \\
\text { Da et al. } 1 \\
\text { Danthine and Donaldson } 1 \\
\text { Daveni and Ilinitch } 1 \\
\text { Derrig and Orr } 1 \\
\text { Duffie } 1 \\
\text { Eiteman et al. } 1 \\
\text { Fabozzi and Francis } 1 \\
\text { Furman and Zitikis } 1 \\
\text { Genton and Ronchetti } 1 \\
\text { Gooding and O'Malley } 1 \\
\text { Grabowski } 1 \\
\text { Hamada } 1 \\
\text { Hawawini } \mathbf{1} \\
\text { Hirshey and Pappas } 1 \\
\text { Howard } 1 \\
\text { Jordan and Miller } 1 \\
\text { Kahn and Grinold } 1\end{array}$ & $\begin{array}{l}\text { Keown et al. } 1 \\
\text { Kothari and Shanken } 1 \\
\text { Levy } 1 \\
\text { Lobe et al. } 1 \\
\text { Mamaysky et al. } 1 \\
\text { Mandelker and Rhee } 1 \\
\text { Murphy } 1 \\
\text { Nagel et al. } 1 \\
\text { Pereiro } 1 \\
\text { Pike and Neale } 1 \\
\text { Reinhart } 1 \\
\text { Rojo } 1 \\
\text { Shapiro } 1 \\
\text { Shenoy } 1 \\
\text { Shirreff } 1 \\
\text { Tole } 1 \\
\text { Turner } 1 \\
\text { Vasicek } 1 \\
\text { Womack and Zhang } 1\end{array}$ \\
\hline
\end{tabular}

\section{Table 4}

Webs and databases cited by the 723 professors that used them

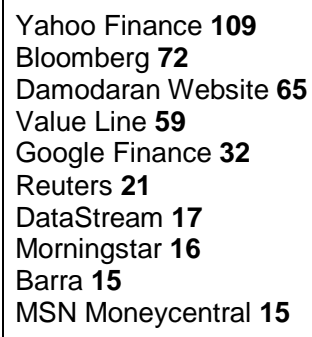

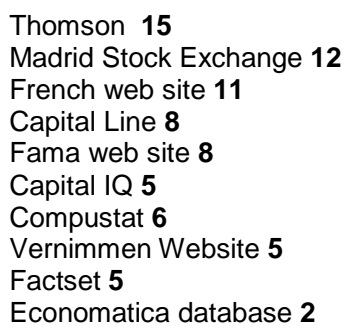

S\&P's Market Insight 2
S\&P NetAdvantage 2
Central Bank Chile $\mathbf{1}$
CNBC $\mathbf{1}$
E TRADE $\mathbf{1}$
ExecuComp $\mathbf{1}$
Fidelity Investments $\mathbf{1}$
Forbes.com $\mathbf{1}$
Hoovers $\mathbf{1}$

Infinancials 1 Marketwatch.com 1

Multex Investor 1

Nat.Stock Exchange India 1

Quote.com 1

Research Insight 1

SMARTMONEY 1

Wikipedia 2

worldexchange.org 1

\footnotetext{
${ }^{2}$ According to Damodaran's website, to estimate the bottom-up beta of a company, "we broke it up into the different businesses and estimate the betas for each business based upon comparable firms."

3 The predicted beta according to Barra that depends on "fundamental risk factors:" industry exposures, size, volatility, momentum, value factors...

4 Damodaran's web page: “Total beta = Market beta / Correlation between stock and market.

This measure is equivalent to dividing the standard deviation of a stock by the standard deviation of the market. For an undiversified investor, it may be a better measure of risk than the traditional market beta. It is useful for computing the cost of equity for a private business with an undiversified owner".
} 


\section{Dispersion of the Betas Provided by Webs and Databases}

But different beta sources provide us with different betas. Table 5 contains betas of three companies provided by the webs and databases used by professors; and it highlights their huge dispersion:

- $\quad$ the betas of Coca-Cola range from 0.31 to 0.8 ;

- $\quad$ the betas of Walt Disney range from 0.72 to 1.39; and

- $\quad$ the betas of Wal-Mart Stores range from 0.13 to 0.71 .

Table 5

Betas of three companies according to the most used webs and databases. May 12, 2009

\begin{tabular}{|c|c|c|c|}
\hline WEB/Database & COCA-COLA & WALT DISNEY & WAL-MART STORES \\
\hline Bloomberg & 0.79 & 1.06 & 0.58 \\
\hline Cnbc & 0.60 & 1.00 & 0.30 \\
\hline Damodaran & 0.61 & 0.88 & 0.19 \\
\hline Datastream & 0.31 & 0.72 & 0.13 \\
\hline Ft.Com & 0.80 & 1.06 & 0.57 \\
\hline Google Finance & 0.60 & 1.03 & 0.26 \\
\hline Hoovers & 0.60 & 1.00 & 0.20 \\
\hline Infomercados & 0.33 & 1.39 & 0.31 \\
\hline Msn Moneycentral & 0.54 & 1.03 & 0.16 \\
\hline Quote & 0.54 & 1.13 & 0.19 \\
\hline Reuters & 0.53 & 1.01 & 0.17 \\
\hline Smartmoney & 0.61 & 1.03 & 0.26 \\
\hline Thomson Banker & 0.55 & 1.09 & 0.38 \\
\hline Value Line & 0.55 & 1.00 & 0.60 \\
\hline Vernimmen Website & - & 1.08 & 0.71 \\
\hline Yahoo Finance & 0.63 & 0.99 & 0.28 \\
\hline Max. & 0.80 & 1.39 & 0.71 \\
\hline Min. & 0.31 & 0.72 & 0.13 \\
\hline
\end{tabular}

Bruner et al. (1998) also found sizeable differences among beta providers: for their sample, the average beta according to Bloomberg was 1.03, whereas according to Value Line it was 1.24.

\section{Schizophrenic Approach to Valuation}

Valuation is about expected cash flows and about required return. We all admit that different investors may have different expected cash flows, but many of us affirm that the required return (discount rate) should be equal for everybody. That is the schizophrenic approach: to be a democrat for the expected cash flows but a dictator for the discount rate.

Most professors teach that the expected cash flows should be computed using common sense and good judgment about the company, its industry, the national economies... However, many professors teach a formula to calculate the discount rate (instead of again using common sense $^{5}$ ). Most professors acknowledge that there are problems estimating two ingredients of the

\footnotetext{
${ }^{5}$ We mean common sense, experience and some financial knowledge.
} 
formula (the beta and the market risk premium), but, nevertheless, they continue using it for several reasons:

- The formula is a theory that "has received a Nobel Prize in Economics"

- "While not perfect, it is used extensively in practice"

- " "If one does not use beta then what is there?"

- "I use all metrics that are available"

- "No substitution so far. There are no better alternatives"

- "There is no other satisfactory tool in finance"

- "We need another model to substitute CAPM and betas and three-factor models"

- " "It is a useful tool to compare one stock with another"

- "Calculated betas are on the CFA exam"

- "Almost every practitioner book uses betas such as the McKinsey publications"

- "Beta allows you to defend a valuation, impress management and come across as a finance guru"

- "Beta is simple and it is used in the real world"

- "In consulting, it is essential to fully support your estimates"

- " "Referees want to see them as the underlying model"

- "Fortune 500 firms use the CAPM to estimate their cost of equity"

- "Regulatory practice often requires it"

- "That point estimate gives the impression of truth"

But business and management (which includes investing and valuation) is about common sense, not about recipes.

\section{Problems Estimating the Betas}

The problems of the betas calculated with historical data are well-known:

1. They change considerably from one day to the next. ${ }^{6}$

2. They depend very much on which stock index is used as the market reference.

\footnotetext{
${ }^{6}$ Some authors, such as Damodaran (2001, p. 72), acknowledge that company betas vary considerably, but claim that industry betas vary very little. They therefore recommend using the calculated beta of an industry. However, although industry betas vary less than company betas, they still vary significantly and using them can lead to serious errors.
} 
3. They depend very much on the historical period (5 years, 3 years...) used. ${ }^{7}$

4. They depend on what returns (monthly, yearly...) are used to calculate them.

5. Very often we do not know if the beta of one company is lower or higher than the beta of another.

6. Calculated betas have little correlation with stock returns.

7. $\beta=1$ has a higher correlation with stock returns than calculated betas for many companies.

8. The correlation coefficients of the regressions used to calculate the betas are very small.

9. The relative magnitude of betas often makes very little sense: companies with high risk often have lower calculated betas than companies with lower risk.

For these nine reasons we can say that:

- The beta calculated with historical data is not a good approximation of the company's beta, or

- the beta of a company (a common figure for all investors) does not exist. ${ }^{8}$

As many professors mention, historical betas (calculated from historical data) are useless to calculate the required return to equity, ${ }^{9}$ to rank portfolios with respect to systematic risk, and to estimate the expected return of companies.

A practical consequence: using a historical beta to value a stock, without analyzing the company's and the industry's future prospects, is very risky and, often, a source of huge errors.

\subsection{Calculated Betas Change Considerably from One Day to The Next}

Figure 1 is an example of how calculated betas change from one day to the next: it shows the historical betas ${ }^{10}$ of Coca-Cola, Walt Disney and Wal-Mart in the month of April 2009: the beta of Coca Cola varies from 0.06 to 0.57 , the beta of Walt Disney varies from 0.66 to 1.07 , and the beta of Wal-Mart varies from -0.05 to 0.5 .

\footnotetext{
${ }^{7}$ Brigham and Gapenski (1977, p. 354, footnote 9) report an illustrative anecdote: “A company that supplied betas told the authors that their company, and others, did not know what was the most appropriate period to use, but that they had decided to use five years in order to eliminate apparent differences between the betas provided by different companies, because big differences undermined the credibility of all of them!"

${ }^{8}$ It would imply that the CAPM does not work. It may be because the required return is affected by other factors, besides the beta; it also may be because, due to the heterenogeity of investors, it does not make sense talking about an "efficient market portfolio;" it also may be because the distribution of expected returns changes with time in a different way for different investors.

${ }^{9}$ We use the term required return to equity instead of cost of equity because there is a radical difference between a required return and a cost. If the manager does not pay the cost of debt, the company disappears, whereas if the company does not provide the required return to equity to their shareholders the managers may suffer some problems.

${ }^{10}$ When estimating betas the standard procedure is to use five years of monthly data and a value-weighted index. This procedure is widely used in academic research and by many commercial beta providers.
} 
Figure 1

Historical betas of Coca-Cola, Walt Disney and Wal-Mart. Betas calculated each day of April 2009 with respect to the S\&P 500 using 5 years of monthly data.

On April 7, 2009, the beta is calculated by running a regression of the 60 monthly returns of the company on the 60 monthly returns of the S\&P 500 calculated on the $7^{\text {th }}$ of the month:

Monthly return of April $=($ TRI of April, 7 / TRI of March, 7) $-1 . \quad$ TRI $=$ Total Return Index

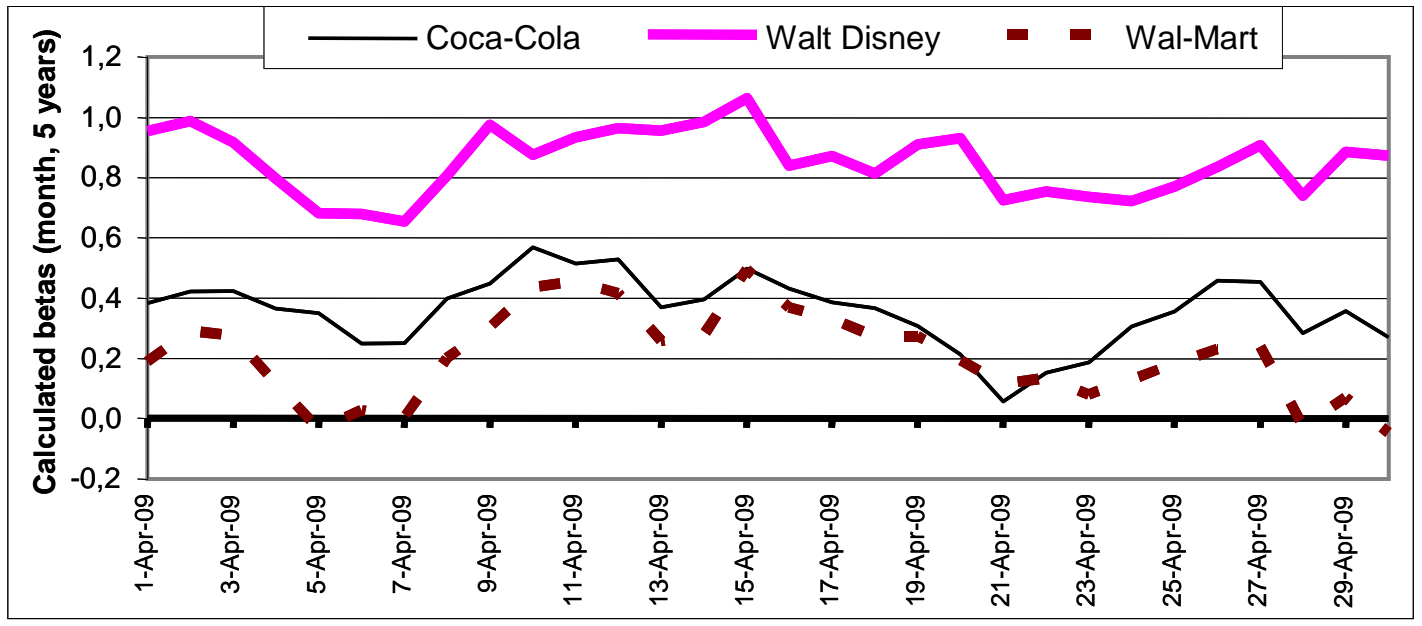

Fernández (2004a) calculates betas of 3,813 United States companies for every day of the month of December 2001 and finds that the median of [Maximum beta/minimum beta] for each company was 3.07. The median of the percentage daily change (in absolute value) of the betas was 20\% for companies and 7\% for industries. The average of [Maximum beta/minimum beta] for each industry was $2.7 .77 \%$ of the companies and 25\% of the industries had, in a month, a maximum beta more than two times bigger than their minimum beta. Fernández (2004b) reaches similar conclusions with data of Spanish companies.

\subsection{Calculated Betas Change Considerably with the Time Period, Frequency and Index Chosen as Reference}

Damodaran (1994) makes this point by calculating the beta of Disney with different intervals ( 3 and 5 years), different frequencies (daily, weekly...) and different market indexes: the beta ranges from 0.44 to 1.38. Damodaran (2001a, page 72) also calculates betas for Cisco versus the S\&P 500 that range from 1.45 to $2.7 .^{11}$

Figure 2 shows the historical betas of Coca-Cola calculated every day of the month of April 2009 using monthly, weekly and daily data of the last five years. It may be seen that betas calculated with daily data change very little (between 0.197 and 0.204), much less than the betas calculated with weekly data (between 0.07 and 0.35 ) and with monthly data (between 0.06 and 0.57).

\footnotetext{
${ }^{11}$ There is a considerable body of literature on intervalling effect and on methods to correct this bias: Altman et al. (1974), Beer (1997), Brailsford and Josev (1997), Cohen et al. (1980, 1983), Dimson (1979), Fama (1970), Handa et al. (1989), Hawawini (1980, 1983), Lee and Kim (1997), Roll (1981), Scholes and Williams (1977), and Smith (1978).
} 
Figure 2

Historical betas of Coca-Cola. Betas calculated each day of April 2009 with respect to the S\&P 500 using 5 years of monthly, weekly and daily data.

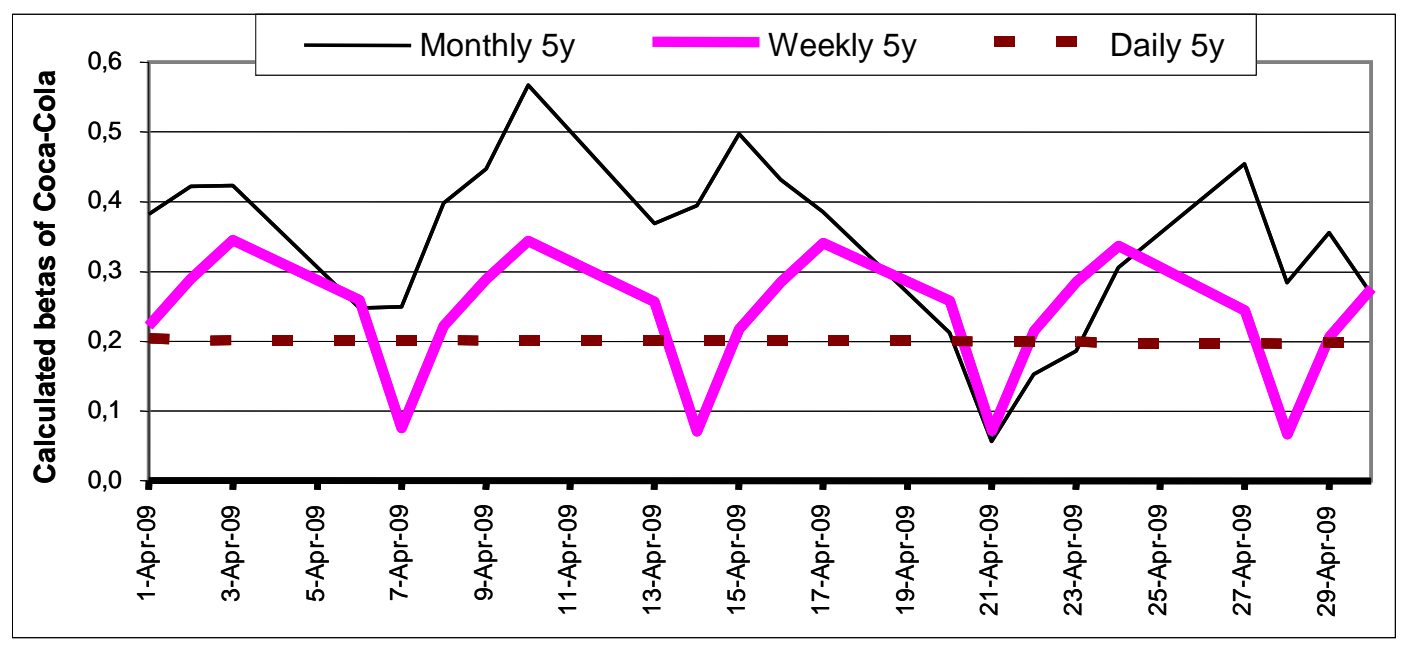

\subsection{Which Company has a Higher Beta?}

Fernández (2004a) ranks each day the companies from 1 (the one with the lowest beta) to 3,813 (the company with the highest beta) and finds that the average change in [Max. ranking - min. ranking] for all 3,813 companies in December 2001 is 1,542 positions. The average beta ranking change from one day to the next was 233 positions; and from one day to the next week 479 positions.

Figure 3 highlights this point. It shows that during the month of December 2001 the beta of AT\&T varies from 0.33 to 1.02 ; the beta of Boeing varies from 0.58 to 1.22 ; and the beta of Coca-Cola varies from 0.55 to 1.11. Which company has the highest or the lowest beta? It depends on which day we choose.

\section{Figure 3}

Historical betas of AT\&T, Boeing and Coca-Cola.

Betas calculated each day of the month of December 2001 with respect to the S\&P 500, i.e., on December 18, 2001 the beta is calculated by running a regression of the 60 monthly returns of the company on the 60 monthly returns of the S\&P 500. The returns of each month are calculated on the 18th of the month:

monthly return of December 18, 2001 $=\frac{\text { total return December } 18,2001}{\text { total return November 18, 2001 }}-1$

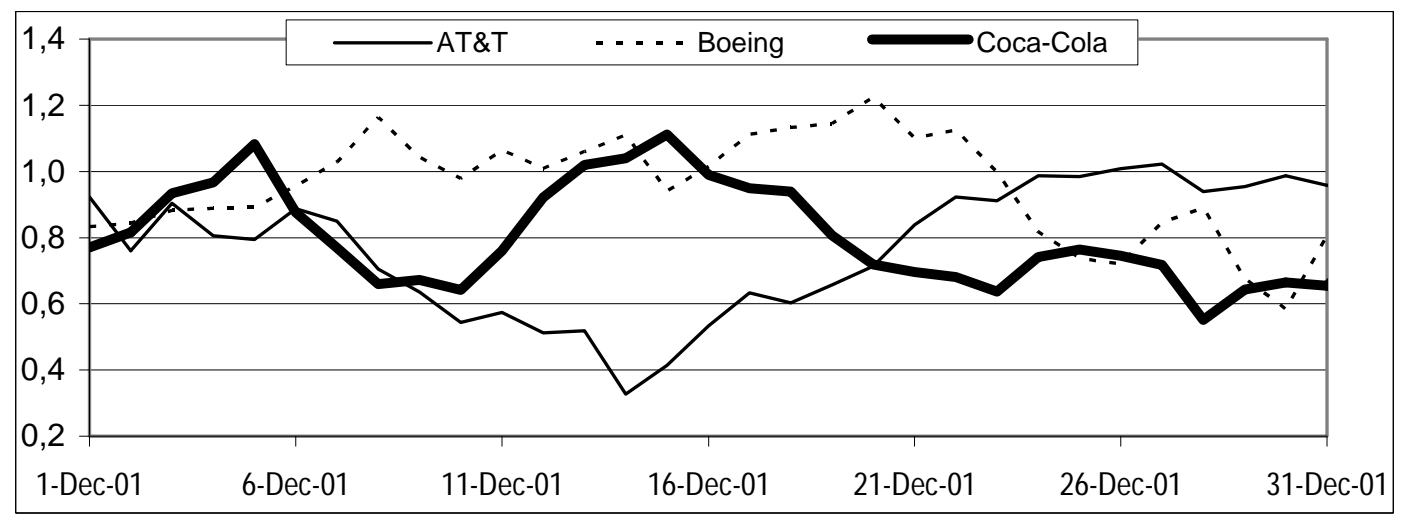

Source of the data: Datastream. 


\subsection{Implications for Constructing Beta-ranked Portfolios}

Fernández (2004a) sorted 3,813 United States companies by decreasing betas on December 1, 2001 and constructed 20 portfolios (portfolio 1 had the companies with the highest betas and portfolio 20 the ones with the lowest betas). Then he calculated the beta of the portfolios every day of the following two months and found that 300 portfolios were misallocated (i.e., on 26 days, portfolio 5 had lower beta than portfolio 6).

He also formed portfolios using the Fama and French (1992) method on December 1 and on December 15, 2001 and found that 71.3\% of the companies change from one portfolio on December 1 to another on December 15.

\subsection{High-risk Companies Very Often have Lower Historical Betas than Low-risk Companies}

Sorting companies by calculated beta, it is easy to find many cases without much economic sense. For example, according to the S\&P 500 betas of table 6, Coca-Cola was the company with lowest beta in 2001, but had a higher beta in 2008 .

\section{Table 6}

Calculated betas of 2 companies (monthly data of 5 years)

\begin{tabular}{|l|c|r|}
\cline { 2 - 3 } \multicolumn{1}{c|}{} & Dec-01 & Dec-08 \\
\hline COCA-COLA & 1.02 & 0.30 \\
\hline WAL-MART STORES & 1.07 & -0.05 \\
\hline
\end{tabular}

Annema and Goedhart (2006) claim that "betas that were artificially low after the market bubble of the 1990s have returned to normal" in 2006. Annema and Goedhart (2003) claimed that "to eliminate the distortion of the high-tech bubble, practitioners should combine historical estimates of betas prior to 1998 with data from after 2000."

\subsection{Industry Betas vs. Company Betas}

Some authors recommend using industry betas, instead of company betas. For example, Copeland, Koller and Murrin (2000) recommend "checking several reliable sources because beta estimates vary considerably... If the betas from several sources vary by more than 0.2 or the beta for a company is more than 0.3 from the industry average, consider using the industry average. An industry average beta is typically more stable and reliable than an individual company beta because measurement errors tend to cancel out." About the CAPM, they conclude: "It takes a better theory to kill an existing theory ${ }^{12}$, and we have not seen the better theory yet. Therefore, we continue to use the CAPM..."

\footnotetext{
${ }^{12}$ We do not agree, we rather think that we can kill a theory if it does not work. Do we need a better cancer treatment to stop using a bad one?

${ }^{13}$ Copeland et al. (2000, p. 225) added "being wary of all the problems with estimating it." Koller et al. (2005, p. 318) added "while keeping a watchful eye on new research in the area."
} 
Industry betas are also unstable. Fernández (2004a) reports that the average daily change (in absolute value) of the industry betas was $16 \%$. On average, the maximum beta of an industry was 2.7 times its minimum beta in December 2001 and January 2002.

\section{7. $\beta=1$ has a Higher Correlation with Stock Returns than Calculated Betas}

Fernández and Bermejo (2009) compute the correlations of the annual stock returns (1989-2008) of the Dow Jones companies with a) $\beta \mathrm{Rm}$; and with b) Rm (the return of the S\&P 500); and find that the second correlation (assuming beta $=1$ for all companies) is higher than the first, on average, and for all companies except Caterpillar and General Motors. Beta $=1$ works better than calculated betas! Not surprisingly, Adjusted betas $(0.67$ calculated beta +0.33$)$ have higher correlation than calculated betas. But Adjusted betas have lower correlation than beta $=1$. They do the exercise with four calculated betas every year end vs. the S\$P 500, using: a) monthly data of last 5 years; b) monthly data of last 2 years; c) weekly data of last 5 years, and d) daily data of last 5 years. They find similar results with the four betas.

\section{Calculating the Required Return to Equity Without Regressions}

The market value of the company's equity is obtained by discounting the expected equity cash flows at the required return to equity (Ke).

We can get the Ke by adding a Company Premium $\left(C_{P}\right)$ to the risk free rate $\left(R_{F}\right)$, the return we can get for sure buying Government Bonds. The magnitude of $C_{P}$ depends on our assessment of the risk of the expected cash flows.

$$
\mathrm{Ke}=\mathrm{R}_{\mathrm{F}}+\mathrm{C}_{\mathrm{P}}
$$

There are 151 respondents to the survey that use this method (without using $\beta$ ) to calculate the Ke. ${ }^{14}$ According to Lobe et al. (2008), "the majority of German firms merely rely on individual risk premiums."

We also can decompose the Company Premium $\left(\mathrm{C}_{\mathrm{P}}\right)$ in two components: the Market Risk Premium (MRP) and the beta ( $\beta$ ). The MRP is the answer to the following question: What incremental return do I require for investing in a diversified portfolio of shares over the riskfree rate? Different companies, different professors and different books may, and in fact do, use different MRPs. ${ }^{15}$ The $\beta$ is a firm-specific parameter that depends on our assessment of the risk of the expected cash flows. $\beta$ it is 0 for Government Bonds, 1 for a diversified portfolio of shares.

$$
\mathrm{Ke}=\mathrm{R}_{\mathrm{F}}+\mathrm{C}_{\mathrm{P}}=\mathrm{R}_{\mathrm{F}}+\beta \mathrm{MRP}
$$

\footnotetext{
14 Another related method is the "Bond premium model": Ke is calculated by adding a premium to the cost of debt of the company.

${ }^{15}$ Fernández (2009) reports the average MRP used in 2008 by United States professors: 6.3\%. The dispersion was high: professors of the same institution had an average range of 3.5\% and professors of the same country $6.9 \%$. He also reports 416 answers from the field: the average MRP used by European Companies in 2008 was 6.4\%, ranging from $2 \%$ to $30 \%$. 
According to the capital asset pricing model (CAPM), all investors should use the same $\beta$ and the same MRP. On top of that, the $\beta$ of each company and the MRP are parameters that "exist" and we should be able to estimate them accurately with appropriate statistical tools. We do not share this view: we think that the $\beta$ of each company and the MRP should be computed for each company and every investor using common sense and good judgment about the management, the company, its industry, the national economies... ${ }^{16}$

\section{Calculating a Qualitative Beta}

Given the instability and the meaninglessness of historical betas, companies are increasingly resorting to calculating a qualitative beta of companies or investment projects. Example: ${ }^{17} \mathrm{~A}$ company uses the MASCOFLAPEC method (from the initials of the parameters used to evaluate the risk of each project, see Table 7) to estimate the beta. Each parameter is scored from 1 to 5 according to its contribution to the risk. Each factor also has to be weighted. In the attached example, the sum of the scores of each parameter, bearing in mind its weight, was 3.5. Multiplying this number by 0.5 , we obtain a beta of 1.75 . Note that with this system (owing to the parameter 0.5 ) the beta can vary between 0.5 and 2.5. If a parameter equal to 0.6 were used, then the beta could vary between 0.6 and 3.0.

\section{Table 7}

Calculation of a qualitative beta

\begin{tabular}{|c|c|c|c|c|c|c|c|c|}
\hline & & & \multicolumn{5}{|c|}{ Risk } & \multirow{3}{*}{$\begin{array}{c}\text { Weighted } \\
\text { risk }\end{array}$} \\
\hline & & & Low & Average & Substantial & High & Very high & \\
\hline \multicolumn{3}{|l|}{ Weight } & 1 & 2 & 3 & 4 & 5 & \\
\hline $10 \%$ & M & Management & 1 & & & & & 0.1 \\
\hline $25 \%$ & $\mathbf{A}$ & Assets: Business: industry/product ... & & & & & 5 & 1.2 \\
\hline $3 \%$ & $\mathbf{S}$ & Strategy & & & & 4 & & 0.1 \\
\hline $15 \%$ & C & Country risk & & & & 4 & & 0.6 \\
\hline $10 \%$ & 0 & Operating leverage & & & & 4 & & 0.4 \\
\hline $15 \%$ & $\mathbf{F}$ & Financial leverage & & 2 & & & & 0.3 \\
\hline $5 \%$ & $\mathbf{L}$ & Liquidity of investment & & & & & 5 & 0.2 \\
\hline $5 \%$ & $\mathbf{A}$ & Access to sources of funds & & & 3 & & & 0.1 \\
\hline $2 \%$ & $\mathbf{P}$ & Partners & & & & 4 & & 0.0 \\
\hline $5 \%$ & $\mathbf{E}$ & Exposure to other risks (currencies...) & & 2 & & & & 0.1 \\
\hline $5 \%$ & C & Cash flow stability & & & 3 & & & 0.1 \\
\hline \multirow{2}{*}{\multicolumn{2}{|c|}{$100 \%$}} & & & & & & & 3.5 \\
\hline & & Beta of equity = & 3.5 & $x$ & 0.5 & $=$ & 1.75 & \\
\hline
\end{tabular}

\footnotetext{
${ }^{16}$ Another method for family business is explained by my friend Guillermo Fraile, IAE professor at Buenos Aires, in his classes: the HMDYWD (initials for How much do you want, Dad?) method. It is not a joke: it does not make much sense to talk about the Ke as a magnitude shared by all investors; but it does make sense to talk about each investor's Ke, including Dad's.

${ }^{17}$ This example is taken from Fernández (2002, p. 212).
} 
Alternatives to the MASCOFLAPEC method include the MARTILLO method and the BAMIFLEX method:
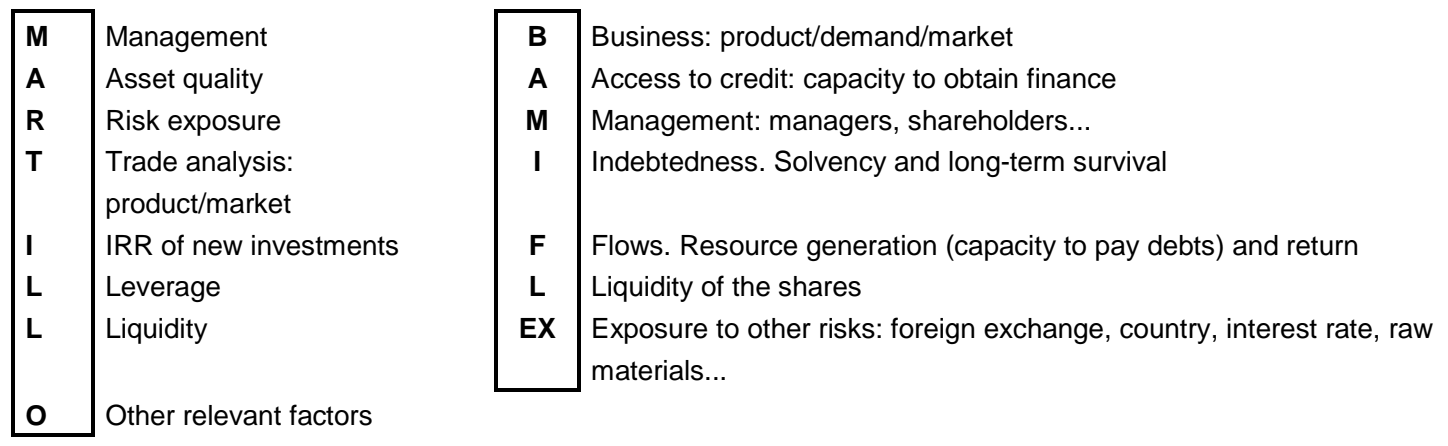

Goldman Sachs recommended the CAMEL method: C (for Capital, referring to leverage); A (for Asset quality, referring to business risk); M (for Management, referring to the confidence we have in the management); E (for Earnings, referring to the volatility of earnings), and L (for Liquidity, referring to the liquidity of the shares).

These methods are simply an aid to common sense. The beta that should be used to value a company will depend on the risk that the valuer sees in the expected flows of the company.

\section{Errors Using Calculated Betas for the Valuation}

The most common error consists of using the historical industry beta, or the average of the betas of similar companies, when this magnitude does not make sense. An example of this error comes from a report written by a financial consulting firm. "The purpose of our study has been to make a professional estimate of the fair value at December, 31, 2001 of the shares of INMOSEV, an unlisted real estate firm whose main business consists of buying land and building houses for resale. The unlevered beta $(B u=0.27)$ is the average of the unlevered betas of listed companies in Spain" (see Table 8).

\section{Table 8}

Betas of listed real estate firms in Spain.

\begin{tabular}{|l|c|c|c|c|c|c|}
\cline { 2 - 7 } \multicolumn{1}{c|}{} & Vallehermoso & Colonial & Metrovacesa & Bami & Urbis & Average \\
\hline Levered beta & 0.49 & 0.12 & 0.38 & 0.67 & 0.42 & $\mathbf{0 . 4 2}$ \\
\hline Unlevered beta & 0.29 & 0.11 & 0.27 & 0.39 & 0.28 & $\mathbf{0 . 2 7}$ \\
\hline
\end{tabular}

Source: SCH.

The resulting unlevered beta (0.27) is so small that it makes no sense to use it to value any company, let alone an unlisted one. Also, these betas (and any others that might have been used) are arbitrary. If we calculate the betas of the five comparable companies on December 31, 2001, using daily and monthly data and different periods, we can obtain average unlevered betas ranging anywhere from 0.22 to 0.85 . Obviously, a valuation that depends on such a shifting and unreliable variable is contrary to all common sense and prudence. 
An investment bank calculation of the beta of an unlisted seed oil company in Ukraine: "The unlevered beta is the average of the following sample:"

\begin{tabular}{|l|c|c|c|c|c|}
\hline Diversified companies of seed oil & $\begin{array}{c}\text { Equity beta } \\
\text { (Bloomberg) }\end{array}$ & Capitalization & Net debt & Tax rate & Unlevered beta \\
\hline Archer Daniels Midland & 0.50 & 7664 & 3933 & $35 \%$ & 0.37 \\
\hline Aarhus Oliefabrik A/S & 0.47 & 920 & 1461 & $36 \%$ & 0.23 \\
\hline Koipe SA & 0.25 & 350 & -133 & $35 \%$ & 0.33 \\
\hline Average & 0.41 & & 0.31 \\
\hline
\end{tabular}

Another error is to assume that the beta calculated from historical data captures the country risk. Interpretation of the beta of a foreign company listed on the stock market in the United States, taken from an investment bank: "The question is: Does the beta calculated on the basis of the company's share price in New York capture the different premiums for each risk? Our answer is yes, because just as the beta captures changes in the economy and the effect of leverage, it must necessarily absorb the country risk."

An investment bank argued that the best estimation of the beta of an emerging market company is the company's beta with respect to the S\&P 500. "The best way to estimate the beta of an emerging economy company with a United States stock market listing is through a regression of the return of the share on the return of a United States stock market index."

Another investment bank assumed that the beta provided by Market Guide with the Bloomberg adjustment incorporates the illiquidity risk and the small cap premium: "The Market Guide beta captures the distorting effects of the share's low liquidity and the small size of the firm through the so-called Bloomberg adjustment formula."

Calculation of the beta for electrical companies done by the Electricity Commission of a European country. "We calculate the betas of all traded European companies. Leveraged betas were calculated using two years of weekly data. The Market Index chosen was the Dow Jones STOXX Total Market Index. There is a great dispersion (from-0.24 to 1.16) and some odd betas (negative and higher than one). We decided to maintain all betas... To unlever the betas, we assumed that the beta of the debt is zero for all companies. Then, the Commission calculates the average of the unlevered betas and re-lever it using an objective debt to equity ratio based on the average debt to equity ratio of comparable companies. The next table shows the betas proponed by the Commission for the transport activity."

Betas according to the European Electricity Commission

\begin{tabular}{|l|c|c|}
\cline { 2 - 3 } \multicolumn{1}{c|}{} & Unlevered beta & Levered beta \\
\hline Transport & 0.326663074 & 0.471870073 \\
\hline
\end{tabular}

The Commission acknowledges that calculated betas have a "great dispersion (from -0.24 to 1.16)." However, the Commission calculates the average of all of them and finally provides betas with a precision of 9 figures after the decimal point! 


\section{Conclusion}

We report 2,510 answers from professors from 65 countries and 934 institutions.

1,791 respondents use betas, but 107 of them do not justify the betas they use. $97.3 \%$ of the professors who justify the betas use regressions, webs, databases, textbooks or papers (Tables 2 , 3 and 4 specify which ones), although many of them admit that calculated betas "are poorly measured and have many problems."

Only $0.9 \%$ of the professors justify the beta using exclusively personal judgment (named qualitative betas, common sense betas, intuitive betas, logical magnitude betas and own judgment betas by different professors).

Exhibits 3, 4 and 5 include interesting comments from 160 professors.

The required return to equity is one of the most important but elusive parameters in finance. According to the CAPM, we should all use the same figure.

Historical betas are not meaningful to calculate the required return on equity. First, because they change dramatically from one day to the next; second, because very often we cannot say with confidence that the calculated beta of a company is smaller or bigger than the beta of another; third, because historical betas do not make much sense in many cases: high-risk companies very often have smaller historical betas than low-risk companies; fourth, because historical betas depend very much on which index, on which data frequency and on which time interval we use to calculate them; fifth, because beta $=1$ works better than calculated betas.

Fama (1976, p. 319) mentioned about the CAPM that: "The fact that assessments are assumed to be common to all investors and that investor perceptions are assumed to be correct allows us to go from theory to data." Later, Fama and French (2004) stated that: "Unfortunately, the empirical record of the model is poor - poor enough to invalidate the way it is used in applications... Evidence mounts that much of the variation in expected return is unrelated to market beta."

Valuation is about expected cash flows and about required return. We all admit that different investors may have different expected cash flows, but many of us affirm that the required return (discount rate) should be equal for everybody. That is the schizophrenic approach: to be a democrat for the expected cash flows but a dictator for the discount rate.

Most professors teach that the expected cash flows should be computed using common sense and good judgment about the company, its industry, the national economies... However, many professors teach a formula to calculate the discount rate (instead of again using common sense). Most professors acknowledge that there are problems estimating two ingredients of the formula (the beta and the market risk premium), but, nevertheless, many of them continue using it. 


\section{Exhibit 1}

\section{Mail Sent on April 2009}

I am doing a survey about the betas that we, professors, use to calculate the required return to equity.

I would be very grateful to you if you kindly reply to the following two questions.

Of course, no individuals or schools will be identified, and only aggregate data will be made public.

Thanks, and best regards, Pablo Fernández. IESE Business School. Spain

\section{2 questions:}

1. I use betas: YES

NO

2. I justify the betas I use:

- I do not justify the betas

- Reference to books or articles

Which ones?:

- Regressions

- Financial websites on Internet

- Other

Comments 


\section{Exhibit 2}

\section{Main Results of the Survey. Details by Country}

\begin{tabular}{|c|c|c|c|c|c|c|c|c|c|c|c|c|}
\hline & \multirow[b]{2}{*}{ 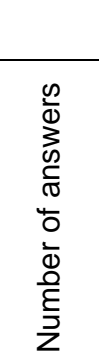 } & \multirow[b]{2}{*}{ 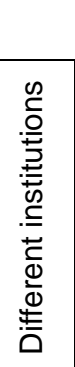 } & \multirow[b]{2}{*}{ 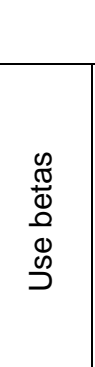 } & \multirow[b]{2}{*}{ 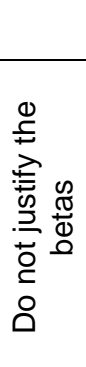 } & \multicolumn{8}{|c|}{ Justify the betas with: } \\
\hline & & & & & 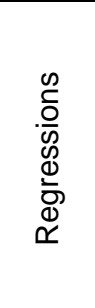 & 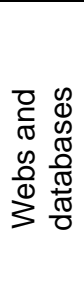 & 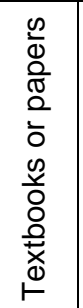 & 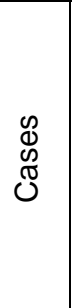 & 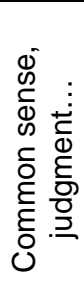 & 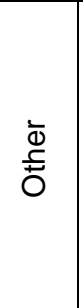 & 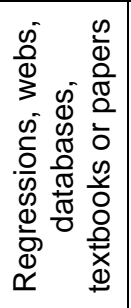 & 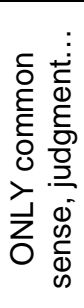 \\
\hline United States & 1,340 & 443 & 995 & 62 & 669 & 461 & 298 & 12 & 12 & 18 & 922 & 6 \\
\hline Spain & 151 & 44 & 103 & 5 & 69 & 23 & 27 & 3 & 6 & 7 & 90 & 6 \\
\hline United Kingdom & 124 & 52 & 83 & 4 & 63 & 34 & 30 & 0 & 2 & 11 & 74 & 0 \\
\hline Germany & 93 & 47 & 50 & 2 & 35 & 15 & 11 & 0 & 0 & 5 & 46 & 0 \\
\hline Canada & 80 & 31 & 58 & 4 & 48 & 23 & 19 & 0 & 0 & 4 & 52 & 0 \\
\hline Australia & 81 & 22 & 50 & 3 & 34 & 19 & 15 & 0 & 1 & 6 & 45 & 1 \\
\hline France & 62 & 30 & 47 & 2 & 38 & 20 & 20 & 0 & 0 & 3 & 43 & 0 \\
\hline Italy & 60 & 28 & 40 & 3 & 29 & 12 & 14 & 0 & 0 & 4 & 35 & 0 \\
\hline Netherlands & 53 & 11 & 30 & 0 & 24 & 10 & 12 & 0 & 1 & 5 & 28 & 1 \\
\hline Switzerland & 34 & 14 & 19 & 2 & 4 & 4 & 7 & 1 & 0 & 4 & 15 & 0 \\
\hline India & 32 & 22 & 31 & 2 & 25 & 13 & 12 & 0 & 0 & 2 & 29 & 0 \\
\hline Hong Kong & 28 & 7 & 23 & 2 & 17 & 8 & 5 & 0 & 0 & 3 & 19 & 0 \\
\hline Taiwan & 22 & 12 & 16 & 1 & 14 & 4 & 0 & 0 & 0 & 1 & 13 & 0 \\
\hline Norway & 21 & 6 & 15 & 3 & 6 & 3 & 7 & 0 & 1 & 2 & 11 & 0 \\
\hline China & 19 & 13 & 14 & 2 & 13 & 2 & 1 & 0 & 0 & 3 & 12 & 0 \\
\hline Belgium & 19 & 6 & 15 & 1 & 12 & 9 & 3 & 0 & 0 & 4 & 13 & 0 \\
\hline Israel & 17 & 6 & 13 & 2 & 10 & 5 & 3 & 0 & 0 & 3 & 11 & 0 \\
\hline Denmark & 17 & 6 & 8 & 1 & 6 & 3 & 4 & 0 & 0 & 2 & 7 & 0 \\
\hline Finland & 17 & 6 & 14 & 0 & 12 & 8 & 5 & 0 & 0 & 3 & 14 & 0 \\
\hline Singapore & 16 & 3 & 15 & 1 & 11 & 6 & 4 & 0 & 0 & 3 & 14 & 0 \\
\hline New Zealand & 13 & 6 & 10 & 0 & 10 & 4 & 3 & 0 & 0 & 2 & 10 & 0 \\
\hline Colombia & 12 & 8 & 10 & 0 & 5 & 10 & 7 & 0 & 0 & 3 & 10 & 0 \\
\hline Austria & 12 & 5 & 8 & 0 & 4 & 4 & 1 & 0 & 1 & 2 & 7 & 1 \\
\hline Portugal & 12 & 7 & 11 & 0 & 9 & 5 & 3 & 0 & 0 & 4 & 11 & 0 \\
\hline Brazil & 11 & 7 & 9 & 0 & 8 & 4 & 6 & 0 & 1 & 2 & 9 & 0 \\
\hline Mexico & 11 & 6 & 9 & 0 & 9 & 8 & 4 & 0 & 0 & 3 & 9 & 0 \\
\hline Korea & 10 & 8 & 9 & 1 & 5 & 2 & 3 & 0 & 0 & 5 & 8 & 0 \\
\hline Greece & 10 & 7 & 7 & 1 & 6 & 0 & 2 & 0 & 1 & 1 & 6 & 0 \\
\hline Ireland & 10 & 5 & 6 & 0 & 4 & 2 & 2 & 0 & 0 & 1 & 6 & 0 \\
\hline Argentina & 9 & 4 & 9 & 0 & 7 & 8 & 5 & 0 & 0 & 2 & 9 & 0 \\
\hline Chile & 9 & 4 & 8 & 0 & 6 & 7 & 3 & 0 & 0 & 3 & 8 & 0 \\
\hline Sweden & 8 & 5 & 5 & 1 & 4 & 0 & 0 & 0 & 0 & 2 & 4 & 0 \\
\hline Japan & 6 & 6 & 6 & 0 & 6 & 1 & 3 & 0 & 0 & 2 & 6 & 0 \\
\hline Czech Rep. & 5 & 3 & 4 & 0 & 4 & 2 & 1 & 0 & 0 & 3 & 4 & 0 \\
\hline Russia & 5 & 5 & 3 & 1 & 1 & 1 & 0 & 0 & 0 & 2 & 2 & 0 \\
\hline Venezuela & 5 & 1 & 4 & 0 & 2 & 4 & 3 & 0 & 0 & 2 & 4 & 0 \\
\hline Other 29 countries ${ }^{*}$ & 54 & 38 & 34 & 1 & 24 & 17 & 12 & 0 & 0 & 7 & 33 & 0 \\
\hline Total & 2,510 & 934 & 1,791 & 107 & 1,253 & 761 & 555 & 16 & 26 & 139 & 1,639 & 15 \\
\hline
\end{tabular}

* Other: Countries with four answers (Romania, Slovakia, South Africa, Turkey); with three answers (Egypt, Lebanon, Peru, Poland); with two answers (Luxembourg, Puerto Rico, Slovenia, Un Arab Emirates) and with one answer (Cyprus, Dubai, El Salvador, Hungary, Jamaica, Kenya, Macau, Macedonia, Malaysia, Mauritius, Pakistan, Palestine, Philippines, Qatar, Singapore, Thailand, Trinidad and Tobago). 


\section{Exhibit 3}

\section{Comments of Professors Who Use Calculated Betas}

1. We have to use historical data to estimate beta - therefore of necessity there is estimation error.

2. Professors should justify the beta information through regression analysis. Research indicates that 5 years' data provides more appropriate results. I used 5 years' monthly closing data to justify CitiBank, Wells Fargo, and Bank of America beta and after regression the result is very close to Beta (available in Reuters).

3. Betas are a useful tool to compare one stock with another. However, beta has a number of weaknesses and limitations. First: Betas are based on historical data and may not be a good indication of the future. Second: There are an infinite number of ways to calculate beta because of the choices of time period (1, 3, 5, 20 years...), prices (open, high, low, close), interval (daily, weekly, monthly), and whether to use a moving average and over what period. Third: The choice of market to which your target company is to be compared is wide (S\&P 500, DJIA, Wilshire 2000, etc.) Fourth: Applying a beta based on historical observations to cash flow estimates of future operations invites problems. For example: changes in leverage (gearing). Using Adjusted Present Value calculations and adjusted betas can overcome some of these problems.

4. When using betas obtained from an Internet source, the same source should be used for all companies being compared to assure the same method was used to calculate each beta. A sensitivity analysis could be conducted by changing beta to determine the effect on the cost of equity, WACC and Net Present Value.

5. Indian betas vary from one year to another and from one source to another. I feel these are highly suspect.

6. I've used downside risk measures, as downside risk, tail measures and downside risk beta.

7. Betas are a primitive model (like a car from before 1900) and more sophisticated models are now available.

8. I explain how betas are computed and I show students how to find betas already computed, and we talk about what a particular beta means. We also discuss the fact the betas are not stable and that the CAPM assumes that the beta is the expected beta, not the historical beta.

9. I use betas... but I use all metrics that are available.

10. Students calculate their own betas about 15-20 different ways using regression. I discuss published sources and their use. In all cases, I point out the underlying volatility of beta depending on the specific calculation approach.

11. Beta use requires judgment. I demonstrate how to calculate betas and highlight the issues with time-line and independent variable selection.

12. Showing regression and sensitivities to choice of time window and sampling frequency to generate both raw and adjusted beta (i.e., Vasicek or Blume beta).

13. I justify the betas by computing them and proving that they are right. References are also made to financial websites.

14. I always emphasize that beta calculations have to be taken with some leeway.

15. I get students to download Thomson One Banker data and then get them to estimate betas via a single index model. Often they are required to compare the results from different frequencies and time spans of data. Also, we get them to produce adjusted betas (e.g., $2 / 3 \times$ estimate $+1 / 3 \times 1$ ).

16. I point out that returns on beta are much flatter than predicted by the CAPM.

17. I discuss the issues of betas and use a robust measure from a reliable source. I make reference to high quality scholarship on the matter. I do NOT confuse beta with standard deviation.

18. If one does not use beta then what is there?

19. I do not use betas for personal investing, but I teach their use with both regressions and secondary sources.

20. It is a simplification of reality, but a useful one.

21. I tell my students to use an average published beta for the stock's systematic risk.

22. We use the equity betas in our text, based on reference to multiple articles-beginning with Sharpe (1964) and Hamada (1972) and going up through current research. 
23. I usually look at a couple of sources before deciding what beta is appropriate.

24. I am becoming more and more skeptical of using betas and believe that the total return for an industry is just as good. I am also investigating the "Total" beta concept. The problem with using betas is that the equity risk premium is suspect and has no standard interpretation. I do not believe that the historical ERP from Ibbotson from 1926 is valid.

25. Our students calculate betas for an industry. They unlever the individual companies; calculate betas using the Fama-French factors; test two hypotheses: that the unlevered betas are identical, and that the factors are priced; estimate the model subject to APT restrictions; and then lever the betas for the individual firms.

26. It is poorly measured, but no substitution so far.

27. I like to show students that this isn't a completely imaginary number, even though there are some good debates about it. Hence, we pull betas off Yahoo finance.

28. Regressions. I do not have much confidence in beta but we don't seem to have any easy substitute.

29. Beta and CAPM don’t work very well. Students need to know what the weaknesses are and why betas often provide misleading results. I demonstrate how misleading betas can be using style index data going back to 1970, which shows a nearly perfect inverse relationship between risk (beta) and return.

30. I use an adjusted beta (2/3 the calculated beta and $1 / 3$ a beta of 1$)$. This is more consistent with actual history.

31. I justify the betas if the published betas are "abnormal" (i.e., negative when you would expect it to be positive).

32. A very relevant question would be: "What is the relevant historical data in calculating the Beta?"

33. The key to using beta is to use multiple sources and estimates and come to a reasonable choice. No single estimate is enough.

34. The most important part of required return is the error factor. $K e=R f+B e t a x(R m-R f)+e 1+e 2$ $+\mathrm{e} 3$ with error representing early stage risk, sovereign risk, currency risk, etc. Applying an error factor is often more important than beta.

35. Sometimes I use qualitative adjustments for betas obtained from regressions, websites or databases.

36. Though beta (CAPM) is old and rough, it helps in stocks portfolio trading.

37. When I cannot find a similar exchange-traded company, I use United States data.

38. The model has received a Nobel Prize in Economics and, while not perfect, is used extensively in practice.

39. There is no other viable approach and it serves as a good guideline for the decision.

40. They are better than not using betas.

41. Betas are well known and relatively easy to use.

42. CAPM does not seem to fit Chinese data.

43. There are no better alternatives.

44. We have found it useful to extend betas by using, for instance, the concept of "beta smile."

45. Betas are historical and they are more for guidance than a total reflection of the "truth."

46. Modeling the cash flows is much more important than the discount rate.

47. Given the lack of alternative, I find no other choice than to use betas.

48. It fails to give meaningful predictions.

49. I normally use Value Line's betas. I am consistent in the use of betas because other sources would differ.

50. I compare the required return to the required return from the bond premium model.

51. Use them to calculate required rates of return on common stock and retained earnings for actual companies. Remember: the two requirements are different!

52. We need to continue to use betas for at least three reasons: 1) still on the CFA exam; 2) the theory is still correct, only the lack of a true market prevents the correct calculation of beta (and there is no good substitute), and 3) need to understand the concept of beta to hedge an equity portfolio using futures contracts. 
53. I show in class the example of IBM when they switched from being just a mainframe computer maker to also doing a lot of IT consulting. Their beta went up by about 0.5 .

54. I emphasize that CAPM is mainly useful in calculating cost of capital for capital budgeting applications; not so much for portfolio investment.

55. I use betas $1 / 3$ input into required return. I justify by $\mathrm{r}$-squares for their reliability.

56. This is a strange survey. If you don't use betas, how do you adjust for risk? Almost every practitioner book uses betas such as the McKinsey publications. I know money managers who use betas; one calculates them using Factset and the Fama French factors.

57. Barra betas seem to be the most soothing to bankers and clients, partly because no one really knows how they are calculated and they are more expensive. The downside is that you pay a lot for them.

58. I justify use of betas by running my own regressions using techniques that have some support in the literature. While GMM/EGARCH receive little use for betas they are econometrically justified.

59. I use whatever is suggested in the teaching note.

60. I have recently used betas derived from options prices. See Christoffersen, Jacobs and Vainberg (2006).

61. I use betas because they're the standard and the best we seem to have for now. But I always reference the articles that explain the problems with beta as well.

62. a) I deal in middle market M\&A. Buyers have an expected ROE in their minds. It does not matter where they get it. If the buyer is a PE, then they build it up starting with what their LPs want and then adding expenses, carry, etc. b) If one is doing a corporate M\&A deal, then beta is used so the analyst or the investment banker can "defend" their valuation, "impress" management and come across as a "finance guru". c) My colleagues in the valuation field do use beta. They use the beta of public companies in the same industry.

63. Beta is a simple method and it is used in the "real world." It is really not so helpful, although easy to use.

64. I use beta in my valuations. In consulting, it is essential to fully support your estimates.

65. Referees want to see them as the underlying model. I need a model anyway, and these are the safe bets that referees will not challenge.

66. If I am in charge of the seller, I argue a beta as low as possible: after dealing many years in academic and professional life with cost of capital, I might summarize my experiences as follows: there does not exist any true/objective cost of capital figure. When calculating cost of capital, there are always discretionary decisions to be made: cost of capital is not a matter of truth/scientific derivation. Therefore I decided not to search for the "true" cost of capital - that would be "love's labour's lost."

67. Students tend to see CAPM as just one recipe from a coking book.

68. CAPM has problems that the academic profession has generally swept under the rug. I had to buy three estimates of industry costs of capital to convince two of my colleagues that CAPM was incorrect.

69. Beta is the first order success and risk factor of any portfolio, the most important parameter for single investors to settle in investing.

70. I definitely use betas, because I haven't yet found a way to avoid teaching CAPM (still looking).

71. Most of the time, I recommend just using a market beta of one. In class, I point out (for the benefit of economists) that betas are elasticities. I have never seen a finance textbook that mentions this.

72. I teach beta to my students because Fortune 500 firms use the CAPM to estimate their cost of equity.

73. I use the beta both in class and for some consulting work. I don't believe a particular beta estimate is justifiable, so I rely on sensitivity analysis to show how our results change given the size of the estimation error. I actually try to put more emphasis on the size of the estimation error than the actual estimate of the beta.

74. If there is better measure of systematic risk as intuitive as beta, I will be glad to use it. 
75. I use the beta in class but with plenty of caution. I tell students "Beta is dead, long live Beta." The use of betas is problematic but there is no other satisfactory tool in finance.

76. I assume that the required return is equal to the expected return on equity.

77. I use beta estimates. True betas can never be measured. I use a mix of regression from market data, web sites, and comparable companies.

78. I am not a big fan of beta as a practical tool, but regulatory and corporate practice often requires it.

79. I do not use betas except for teaching purposes. I researched the predictability for stock returns. I found worse out of sample predictive power for future returns using betas than when the market average return is used.

80. Because beta remains prevalent in the financial websites commonly used by investors (Morningstar, Yahoo Finance, etc.), it would be a mistake not to instruct students on its use.

81. I point to an article I once read that Merrill Lynch at one time used a 56-factor model in their equity analysis.

82. I suggest students check many sources and make an informed decision. It is, after all, an art, not a science!

83. In light of Fama and French, you even have to wonder about the use of betas, but, yes, I do make use of them. When I assign valuation projects, I generally prescribe the cost of equity (or WACC) that students are to use in order to "take one important variable off the table."

84. Betas are a simple and useful tool for capital budgeting, not predicting future returns.

85. For individual stocks, betas are hard to estimate, so an estimate of 1 is perhaps as good as any other. This being said, when the regression results seem to be accurate and stable, I would be in favor of using the beta estimate (eventually with a Blume correction). For portfolios it makes more sense to use betas as these estimates tend to be more accurate.

86. Most of the time, we justify use of betas through underlying theory and students become convinced. We use Regression Analysis to derive the value of beta and then also provide necessary interpretation of other statistics like R2 along with beta analysis. I found that students are quite excited about betas.

87. Although not perfect, beta can be justified by looking at regression of a stock's return against market return. Some stocks have steeper slopes than others, which imply higher risk.

88. When the company does not have its stocks traded, I usually look for the mean or median beta of comparable companies. In this case, I adjust the beta of comparable companies in order to avoid a bias from different capital structures ("de-leveraging" and "re-leveraging" the beta).

89. I explain the basic concept of variability to further explain beta. 


\section{Exhibit 4}

\section{Comments of Professors Who Use "Common Sense"18 Betas}

1. I use them in a general sense and I think many on the Street do as well; "high," "low," or "average" beta stocks. You can't measure them accurately.

2. I use regression, webs, and the comments of financial analyst contacts to obtain betas. I may subjectively adjust them. For example I do not believe the PepsiCo beta of 0.6 in Value Line. So I use a 1.0 as I believe that PepsiCo's systematic risk is $=$ or $>$ the market.

3. Regressions (1-5 years daily data). Where no information available, ad hoc betas like 0.8, 1.0 and 1.2 for below average, average and above average risk.

4. I always use 1.

5. My own estimation combining regression, judgment and adjustment for specific reasons/events.

6. Common Sense. I always emphasize that this is the most important ingredient. E.g., if a regression tells me that Marks and Spencer has a lower beta than Tesco (note: they're both supermarkets), you should not trust the regression, and feel confident to overrule it.

7. Given the instability of estimated betas, I check the estimated beta of the company against leverage adjusted betas for "comparables". Also may use range of WACCs based on range of betas. However, the main impact of the uncertain estimates is to heavily weight the results of a competitive/strategic analysis.

8. I first decide on a required return and then I derive a beta to justify it.

${ }^{18}$ Also named personal judgement, qualitative betas, common sense betas, intuitive betas, logical magnitude betas and own judgement betas by different professors. 


\section{Exhibit 5}

\section{Comments of Professors Who Do Not Use Betas}

1. I have never believed the theory, which means that one is sampling from a fixed distribution. But where does that distribution come from?

2. Based on Fama and French (1998), beta is "dead." So, I don't use it.

3. I do not use the betas. Weak hypothesis of normality.

4. I do not use beta as a measure of risk. Beta, after all, does not consider price.

5. The beta calculation is deductively correct. However, our belief in beta, in any shape or form, is unjustified. The whole calculation is essentially a waste of time. As is the CAPM.

6. I teach CAPM in class, but I do not believe that betas are useful to determine the required return on equity. For that, you need an estimate of the market's future/expected return, which is anyone's guess, as is the return on equity itself, so in my opinion you are only shifting the problem.

7. My method begins with an analysis of technology relationships and moves from that base into stock analysis. My method calls for me to sell an individual stock out of a client's account when it reaches a $40 \%$ gain.

8. I do not use betas when investing in individual stocks but find them useful when looking at mutual fund performance.

9. The use of betas is a completely arbitrary "rule" in valuation. There's nothing that exists in nature that ties betas to the "correct" cost of equity. One's cost of equity is a personal decision which should be based on assumed upside/downside, and one's tolerance for LOSING MONEY (which is different from what beta defines). Valuation is an art as much as a science.

10. I don't use them in anything I do, but I do teach them to people who (some) will.

11. I do not use beta and I do not believe in it.

12. I do not use betas at all since I do not believe CAPM is a reliable model.

13. There is no "required" return to equity. It is something that textbook authors write about, but they do that mainly because other textbook authors write about it, and they do not know what else to write about.

14. Real estate investment analysis is too local and the sample set size is too small for a reliable estimated beta.

15. I used to use betas in quantitative research years ago, with unsatisfactory results.

16. I do not research using betas. My research is related to asset pricing using martingale techniques.

17. Beta is 'bull-hockey.' The underlying assumptions are not realistic nor understood by most users. Moreover, most analysis misapplies the betas - even if there was a way to compute a meaningful number. The betas do not give an indication of investment risk. Better to approach risk from a different direction entirely.

18. I can't really answer this question as I believe the required return on equity is determined by a multifactor model, not by the CAPM. As has been argued by Campbell, Vuolteenaho, and Polk, I think the cash-flow component of beta has a much higher price of risk than the discount-rate component.

19. I don't use betas because I work on non traded companies. I use valuation models derived from the CAPM.

20. I show why: (1) markets are inefficient [long term] because of economic externalities - government regulation, change of managers due to retirement and death, etc.; (2) betas are not stable over time, they are based on historical data which may change markedly in the future, and (3) when computing betas there is the problem of determining the frequency of the data, which can alter your results.

21. CAPM does not give any information. Roll (1977- 2 articles) has pointed out that using CAPM (beta) is tautological to market efficiency which means that the market value must by correct.

22. This is outside my domain entirely. It is like asking me about baptism or rollerblading.

23. To calculate the cost of equity capital for the firms of one industry, I use size adjusted capital asset pricing model from Ibbotson Associates (2008), by assuming beta=1 for every firm.

24. I think in general it's useless.

25. We do not calculate required returns to equity. But we calculate "expected average returns," by using long-run risk premia (e.g., over money market) for various asset classes. 
26. Sharpe (1964) makes it clear that beta is a prospective measure and it is impossible to measure it given that expectations are non-homogenous in real markets. I do not use betas, as they relate only to financial assets and I value enterprises as real capital. Other models of discount rates are in use, based on the Kantorovich-Lurje optimization doctrine (SOFE). In financial institutions, I'm mostly looking at tracking errors and not betas.

27. As a developer of Minsky's "Financial Instability Hypothesis" and an honorary member of the "Econophysics" group, I regard the whole concept of betas as delusional.

28. We enter the market when there is a huge drop and sit there waiting for it to rise; we get out when there is a huge rise/hype and sit there waiting for it to drop. Betas are for academia and large financial corporations, which may not even do better than a snake: wait and catch.

29. There seems no strong evidence base to refute a null hypothesis that most betas are unity.

30. The CAPM provides no useful information for making business decisions.

31. I don't have confidence using beta, because it shifts dramatically over five year periods. Therefore, it doesn't help much in the real world.

32. I do not use betas because they are based on the assumption that the market is perfectly efficient. Also, as a selective contrarian investor, I do not believe that they accurately represent the risk of a stock.

33. Is this the result of some idiotic comment by an anonymous moron journal referee?

34. I TEACH betas only so students know what they are and how uninformed people use them but I DO NOT USE them. I discuss how most professors and practitioners do not understand where betas come from and discuss the evidence that supports the position that simple single factor models (like the CAPM) are inferior to multi-factor models for estimating risk adjusted returns.

35. Not a meaningful concept - neither stable nor are the assumptions leading to betas realistic.

36. I do not use betas but it does not mean that I do not advocate CAPM. I simply give a required return to equity, and tell my students you might get this from CAPM, the three factor model, or even from your consulting firm (like Ibbotson Associates).

37. I use chaos theory to guide my decisions. So far I have only lost about $20 \%$ in this market and have not moved my mix since before the decline.

38. The so called 'cost of equity' is again a mythical academic exercise. The true cost is not what shareholders expect, but what a company can afford to pay.

39. I teach that if they use beta in their investment decisions, it will cost them dearly. Beta is one of the most destructive ideas in finance. It is worthless in practice.

40. I do not use betas because their use presumes normal distributions of returns.

41. I did a little check as follows: a brand new textbook written last year had a page on betas for about a dozen stocks. I thought to check those as of today - that is within 12 months of the book being written - ALL of the betas were strongly different, and many had moved from being above one to below one, or the other way around. Betas are very unstable, not reliable, and I find their use in predictive required returns rather spurious.

42. The CAPM is useless.

43. I do not use betas, because I prefer to value equity using fundamentals rather than cross-sectional pricing. 1) Cross-sectional pricing means that a stock is priced off the market. 2) The market is just the sum of individual stock prices. And so 1) +2 ) => a kind of circular logic which permits bubbles. I therefore prefer to use fundamentals like the discounted cash flows.

44. I view beta as a measure of the systematic risk of a stock. However, I do not believe it can explain the required return to equity.

45. Individual firm betas are inherently unstable and non-stationary. Portfolio betas are known to be relatively more stable and stationary than individual security betas. Betas are single period devices and being so, there are an infinite number of betas: one corresponding to each possible period.

46. I used them many years ago, but it has become obvious that they are of limited value.

47. While the distinction between alphas and betas is interesting conceptually, I do not believe that their estimation is something we should strongly rely upon in explaining equity returns. The desire to gamble and financial fads of the moment make it difficult to expect regression analysis to uncover stable fundamentals here. 
48. I find the whole use of betas as an acceptable proxy for risk very unconvincing.

49. I do not use beta at all, nether do I like the CAPM. It simply has no practical significance.

50. Beta is a historical relationship, the required rate of returns calculation requires a forecast; beta does not serve this function. We are confusing risk with uncertainty. The required rate of returns has a large uncertainty component. I do not use beta. If you do then you get it right about the same number of times that you get it wrong - the required rate of returns.

51. I do not believe there is such a thing as "required" return on equity; there may be an expected return, and for that I use an approximate beta for classes of stock, e.g., blue chip, small cap, etc..

52. I do not use CAPM because I think ICAPM is a better model.

53. I have proof that standard neoclassical economics and finance is internally inconsistent.

54. Beta coefficients are not used as an investment tool in the Turkish Stock Market.

55. Betas have more usefulness as indicators of good "options" plays. High beta stocks are much more likely to have good price action. Low beta stocks are better candidates for writing covered calls.

56. I teach that the CAPM is not a very good model and is not worth the effort. Students simply use benchmark expected returns for capital budgeting and alternative pricing models like Fama and French for investments.

57. I do not use betas for explanation purposes because of statistical and estimation error. I do believe that betas are $\mathrm{OK}$ for forecast purposes like ranking stocks on future risk but that there are better measures for that purpose.

58. Since market turnover is slow, betas are not a real issue in real estate. Even with REITs we look at longer term results.

59. The students had a case due on LSB Industries. Yahoo!Finance reported that LSB had a beta of -0.24 . Why isn't it giving us a reasonable number? Beta isn't a precise estimate, but almost everyone reports a point estimate. That point estimate gives the impression of "truth" when in fact the estimate may not be very good at all. The 95 percent confidence interval for LSB's beta in 2001 was -2 to 1.6! That's a huge range. Such a wide interval means that any estimate of beta is meaningless for LSB and shouldn't be used. Still, because it's published, students and most others don't question whether it's a good estimate or not.

60. When you estimate beta, you have to decide how many years, months, or days to use. You also have to decide whether to use daily, weekly, or monthly returns. Finally, you have to decide which market index to use: NASDAQ, S\&P 500... Depending on your choice, you can get very different point and interval estimates.

61. The beta's confidence interval is enormous which turns any decision based on it in an astrological prediction.

62. I don't use betas at all in my research, as I am more using queuing theory and occasionally simulation. 


\section{Exhibit 6}

\section{Literature Review About Capm}

The CAPM of Sharpe (1964), Lintner (1965), and Mossin (1966) is predicated on the assumption of a positive systematic risk-return tradeoff, and asserts that the expected return for any security is a positive function of three variables: expected beta, expected market return, and the risk-free rate. The basic assumptions of the CAPM are:

1. Investors have homogeneous expectations about asset returns that have a joint normal distribution.

2. Investors are risk-averse individuals who maximize the expected utility of their end-of-period wealth.

3. Markets are frictionless and information is costless and simultaneously available to all investors; there are no imperfections such as taxes, regulations, or restrictions on short selling.

4. There exists a risk-free asset such that investors may borrow and lend unlimited amounts at the risk-free rate.

However, subsequent works by (among many others) Basu (1977), Banz (1981), Reinganum (1981), Litzenberger and Ramaswamy (1979), Keim $(1983,1985)^{19}$ and Fama and French (1992) suggest that either:

1. Expected returns are determined not only by the beta and the expected market risk premium, but also by non-risk characteristics such as book-to-market ratio, firm size, price-earnings ratio and dividend yield. It implies that the CAPM is misspecified and requires additional factors, other than beta, to explain security returns.

2. The historical beta has little (or nothing) to do with the expected beta. To put it another way: the problems of measuring beta are systematically related to variables such as firm size and book-tomarket ratio. And, also, the historical market risk premium has little (or nothing) to do with the expected market risk premium.

3. The heterogeneity of expectations ${ }^{20}$ in cross-section returns, volatilities and covariances, and market returns is the reason why it makes no sense to talk about an aggregate market CAPM, although at the individual level expected CAPM does work. It means that, while individuals are well characterized by CAPM, and each individual uses an expected beta, an expected market risk premium and an expected cash flow stream to value each security, all individuals do not agree on these three magnitudes for each security. Consequently, it makes no sense to refer to a "market" expected beta for a security or to a "market" expected market risk premium (or to a "market" expected cash flow stream), for the simple reason that they do not exist.

\footnotetext{
19 Basu (1977) found that low price/earnings portfolios have higher returns than could be explained by the CAPM. Banz (1981) and Reinganum (1981) found that smaller firms tend to have high abnormal rates of return. Litzenberger and Ramaswamy (1979) found that the market requires higher rates of return on equities with high dividend yield. Keim (1983, 1985) reports the January effect, that is, seasonality in stock returns. Tinic and West (1984) reject the validity of the CAPM based on intertemporal inconsistencies due to the January effect.

${ }^{20}$ Lintner (1969) argued that the existence of heterogeneous expectations does not critically alter the CAPM in some simplified scenarios. In some cases, expected returns are expressed as complex weighted averages of investors's expectations. But if investors have heterogeneous expectations of expected returns and covariance matrix, the market portfolio is not necessarily efficient and this makes the CAPM non-testable. Lintner (1969) says "in the (undoubtedly more realistic) case with different assesments of covariance matrices, the market's assessment of the expected ending price for any security depends on every investor's assessment of the expected ending price for every security and every element in the investor's assessment of his $N x N$ covariance matrix ( $N$ is the number of securities), as well as the risk tolerance of every investor."
} 
We may find out an investor's expected IBM beta by asking him. However, it is impossible to determine the expected IBM beta for the market as a whole, because it does not exist. Even if we knew the expected market risk premiums and the expected IBM betas of the different investors who operated on the market, it would be meaningless to talk of an expected IBM beta for the market as a whole. The rationale for this is to be found in the aggregation theorems of microeconomics, which in actual fact are non-aggregation theorems. A model that works well individually for a number of people may not work for all people together. $^{21}$

The problem with the beta is that investors do not have homogeneous expectations. If they did, it would make sense to talk of a market risk premium and of an IBM beta common to all investors because all investors would hold the market portfolio. However, expectations are not homogeneous.

\begin{tabular}{|c|c|}
\hline CAPM - Homogeneous expectations & Heterogeneous expectations \\
\hline $\begin{array}{c}\text { All investors have equal expectations about asset returns } \\
\text { that have a joint normal distribution }\end{array}$ & $\begin{array}{c}\text { All investors DO NOT have equal expectations } \\
\text { about asset returns. Asset returns DO NOT have a } \\
\text { joint normal distribution }\end{array}$ \\
\hline
\end{tabular}

All investors use the same required return to equity for each company. All investors use the same market risk premium and the same beta.

Each investor uses a different required return to equity for each company. Investors use different market risk premia and different betas.

\begin{tabular}{|c|c|}
\hline All investors hold the market portfolio & Investors hold different portfolios \\
\hline \multicolumn{2}{|c|}{} \\
\hline Betas may be estimated with regressions & Regressions are useless \\
\hline
\end{tabular}

\section{Measurement errors and problems}

Original tests of the CAPM focused on whether the intercept in a cross-sectional regression was higher or lower than the risk-free rate, and whether stock individual variance entered into cross-sectional regressions.

Fama (1976, p. 319) already expresses concerns about the empirical validity of the CAPM: "the expected values and covariances that appear in the valuation formulae are investor assessments of parameters that vary from one investor to another. It is not even logical to talk about estimates of these assessments obtained from market data... The fact that assessments are assumed to be common to all investors and that investor perceptions are assumed to be correct allows us to go from theory to data."

Scholes and Williams (1977) found that with nonsyncronous trading of securities, ordinary least squares estimators of beta coefficients using daily data are both biased and inconsistent.

Roll (1977) concludes that the only legitimate test of the CAPM is whether or not the market portfolio (which includes all assets) is mean-variance efficient. The Roll critique does not imply that the CAPM is an invalid theory. However, it does mean that tests of the CAPM must be interpreted with great caution. Roll (1981) suggests that infrequent trading of shares of small firms may explain much of the measurement error in estimating their betas.

Constantinides (1982) points out that with consumer heterogeneity "in the intertemporal extension of the Sharpe-Lintner CAPM, an asset's risk premium is determined not only by its covariance with the market return, but also by its covariance with the $m-1$ state variables" ( $m$ is the number of heterogeneous consumers). He also points out that the assumption of complete markets is needed for demand aggregation.

\footnotetext{
${ }^{21}$ As Mas-Colell et al. (1995, p. 120) say: "It is not true that whenever aggregate demand can be generated by a representative consumer, this representative consumer's preferences have normative contents. It may even be the case that a positive representative consumer exists but that there is no social welfare function that leads to a normative representative consumer."
} 
Lakonishok and Shapiro $(1984,1986)$ find an insignificant relationship between beta and returns and a significant relationship between market capitalization and returns.

Shanken (1992) presents an integrated econometric view of maximum-likelihood methods and two-pass approaches to estimating historical betas.

Roll and Ross (1994) attribute the observed lack of a systematic relation between risk and return to the possible mean-variance inefficiency of the market portfolio proxies.

Shalit and Yitzhaki (2002) argue that the Ordinary Least-Squares regression estimator is inappropriate for estimating betas. They suggest alternative estimators for beta that are robust with respect to extreme fluctuations in the market return. Using CRSP daily data from 1984 to 1993, they eliminate the highest four and the lowest four market returns and show that the betas of $75 \%$ of the firms change by more than one standard error.

Avramov (2002) uses Bayesian model averaging to analyze the sample evidence on return predictability in the presence of model uncertainty. The analysis reveals in-sample and out-of-sample predictability, and shows that the out-of-sample performance of the Bayesian approach is superior to that of model selection criteria. Small-cap value stocks appear more predictable than large-cap growth stocks. She shows that model uncertainty is more important than estimation risk, and investors who discard model uncertainty face large utility losses.

According to Kogan, Gomes and Zhang (2003) "size and book-to-market play separate roles in describing the cross-section of returns. These firm characteristics appear to predict stock returns because they are correlated with the true conditional market beta of returns." Avramov and Chordia (2001) test whether the Kogan et al. (2003) scaling procedure improves the performance of the theoretically motivated CAPM and consumption CAPM. The evidence shows that equity characteristics often enter beta significantly. However, "characteristic scaled factor models" do not outperform their unscaled counterparts.

The poor performance of the CAPM has inspired multiple portfolio-based factors.

The article that dealt the hardest blow to the CAPM was that published by Fama and French (1992). This article showed that in the period 1963-1990, the correlation between stocks' returns and their betas was very small, while the correlation with the companies' size and their price/book value ratio was greater. They concluded "our tests do not support the most basic prediction of the Sharpe-Lintner-Black Capital Asset Pricing Model that average stock returns are positively related to market betas". The authors divided the shares into portfolios and found that the cross-sectional variation in expected returns may be captured within a three-factor model, the factors being:

- $\quad$ the return on the market portfolio in excess of the risk-free rate

- a zero net investment portfolio that is long in high book-to-market stocks and short in low book-to-market stocks

- $\quad$ a zero net investment portfolio that is long in small firm stocks and short in large firm stocks.

However, Griffin (2002) concludes that there are no benefits to extending the Fama and French threefactor model to a global context. Country-specific three-factor models are more useful in explaining stock returns than are world and international versions.

Lakonishok et al. (1994) argue that the size and book-to-market effects are due to investor overreaction rather than compensation for risk bearing. According to them, investors systematically overreact to corporate news, unrealistically extrapolating high or low growth into the future. This leads to underpricing of "value" (small capitalization, high book-to-market stocks) and overpricing of "growth" (large capitalization, low book-to-market stocks). 
Kothary et al. (1995) point out that using historical betas estimated from annual rather than monthly returns produces a stronger relation between average return and historical beta. They also claim that the relation between book-to-market equity and average return observed by Fama and French (1992) and others is seriously exaggerated by survivor bias in the Compustat sample used. They conclude that "our examination of the cross-section of expected returns reveals economically and statistically significant compensation (about 6 to 9\% per annum) for beta risk."

Pettengill et al. (1995) find a "consistent and highly significant relationship between beta and crosssectional portfolio returns" and insist that "the positive relationship between returns and beta predicted by CAPM is based on expected rather than realized returns." Elsas et al. (2000) follow the Pettengill et al. (1995) methodology for the German market and find a positive and statistically significant relation between beta and return in our sample period 1960-1995 as well as in all subperiods that they analyze: "Our empirical results provide a justification for the use of betas estimated from historical return data by portfolio managers."

Fama and French (1996) argue that survivor bias does not explain the relation between book-to-market equity and average return, and that beta alone cannot explain expected return.

Kothary and Shanken (1999) insist on the fact that Fama and French (1992) tend to ignore the positive evidence on historical beta and to overemphasize the importance of book-to-market. They claim that, while statistically significant, the incremental benefit of size given beta is small. They also claim that book-to-market is a weak determinant of the cross-sectional variation in average returns among large firms.

Cremers (2001) claims that there is no clear evidence against the CAPM because it is difficult to reject the joint hypothesis that the CAPM holds and that the CRSP value-weighted index is efficient. He also claims that the poor performance of the CAPM seems often due to measurement problems of the market portfolio. He concludes that "according to the data, the CAPM may still be alive."

Bartholdy and Peare (2001) investigate the usefulness of the standard recommendation of using five years of monthly data and a value-weighted index for calculating the beta and find that five years of monthly data and an equal-weighted index provide the most efficient estimate of the beta. They also find that the ability of historical betas to explain differences in returns in subsequent periods ranges from a low of $0.01 \%$ to a high of $11.73 \%$ across years, and at best 3\% on average. Based on these results, they say "it may well be appropriate to declare beta dead."

Chung et al. (2001) use size-sorted portfolio returns at daily, weekly, quarterly and semi-annual intervals and find in every case that the distribution of returns differs significantly from normality. They also show that adding systematic co-moments (not standard) of order 3 through 10 reduces the explanatory power of the Fama-French factors to insignificance in almost every case.

Berglund and Knif (1999) propose an adjustment of the cross-sectional regressions of excess returns against betas to give larger weights to more reliable beta forecasts. They find a significant positive relationship between returns and the beta forecast when the proposed approach is applied to data from the Helsinki Stock Exchange, while the traditional Fama-MacBeth (1973) approach as such finds no relationship at all.

Koutmos and Knif (2002) propose a dynamic vector GARCH model for the estimation of time-varying betas. They find that in 50\% of the cases betas are higher during market declines (the opposite is true for the remaining 50\%). They claim that the static market model overstates unsystematic risk by more than $10 \%$ and that dynamic betas follow stationary, mean reverting processes.

Markowitz (2005) concludes that "40 years later, in the face of the empirical problems with the implications of the model, we should be cognizant of the consequences of varying its convenient but unrealistic assumptions." 


\section{References}

Achelis, S. B. (2000), “Technical Analysis from A to Z,” 2nd ed., McGraw Hill.

Adsera, X. and P. Vinolas (1997), "Principios de valoración de empresas,” Editorial Deusto.

Alexander, G., W. Sharpe, and J. Bailey (2003), "Fundamentos de inversiones: Teoría y práctica," Mexico, $3^{\text {rd }}$ ed., Pearson.

Altman, E., B. Jacquillat and M. Lavasseur (1974), "Comparative Analysis of Risk Measures: France and United States,” Journal of Finance 29, pp. 1495-1511.

Altug, S. and P. Labadie (2008), “Asset Pricing for Dynamic Economies,” Cambridge University Press.

Anderson, R. C. and D. R. Fraser (2000), "Corporate control, bank risk taking, and the health of the banking industry," Journal of Banking \& Finance, 24 (8), pp. 1383-1398.

Annema, M. and M. Goedhart (2003), “Better Betas," McKinsey on Finance, winter, pp. 10-13.

Annema, M. and M. Goedhart (2006), “Betas: Back to normal," McKinsey on Finance, 20, summer, pp. 14-16.

Apap, A. (2006), “Portfolio Planning for Individual Investors,” Bosworth-Bradley Publishing.

Avramov, D. and T. Chordia (2001), “Characteristic Scaled Betas,” SSRN no. 276654.

Baesel, J. B. (1974), "On the assessment of risk: Some further considerations," Journal of Finance 24, (5), pp. 1491-1494.

Banz, R. W. (1981), “The Relationship Between Return and market Value of Common Stocks," Journal of Financial Economics, 9, pp. 3-18.

Bartholdy, J. and P. Peare (2000), "Estimating the Cost of Equity," Aarhus School of Business, Working Paper.

Bartholdy, J. and P. Peare (2001), "The Relative Efficiency of Beta Estimates," Aarhus School of Business.

Basu, S. (1977), "Investment Performance of Common Stocks in Relation to their Price-Earnings Ratios: A Test of Efficient Market Hypothesis," Journal of Finance, 32, pp. 663-682.

Basu, S. (1983), "The Relationship Between Earnings Yield, Market Value and the Return for NYSE Common Stocks: Further Evidence," Journal of Financial Economics, 12, pp. 129-156.

Beaver, W., P. Kettler, and M. Scholes (1970), "The association between market determined and accounting determined risk measures,” The Accounting Review, 45 (Oct.), pp. 654-682.

Beer F. M. (1997), "Estimation of Risk on the Brussels Stock Exchange: Methodological Issues and Empirical Results," Global Finance Journal, 8, pp. 83-94.

Bekaert, G. and R. J. Hodrick (2008), “International Financial Management,” Pearson Education. 
Berglund, T. and J. Knif (1999), "Accounting for the Accuracy of Beta Estimates in CAPM Tests on Assets with Time-Varying Risks," European Financial Management, Vol. 5, No. 1.

Berk, J. and P. DeMarzo (2006), “Corporate Finance,” Pearson.

Berk, J., P. DeMarzo, and J. Harford (2008), "Fundamentals of Corporate Finance," Pearson Education.

Bernstein, P. L. (1992), "If Beta is Dead, Where is the Corpse?," Forbes, July 20, 1992, p. 343.

Blake, D. (1999), "Financial Market Analysis," $2^{\text {nd }}$ ed., John Wiley and Sons.

Blume, M. E. (1975), "Betas and their regression tendencies," The Journal of Finance, 30 (3): pp. 785-795.

Bodie, Z., A. Kane, and A. J. Marcus (2004), "Investments," $6^{\text {th }}$ ed., N.Y., McGraw Hill.

Booth, L. (1999), "Estimating the Equity Risk Premium and Equity Costs: New Ways of Looking at Old Data," Journal of Applied Corporate Finance, Vol. 12, No. 1, pp. 100-112.

Brailsford J. T. and T. Josev (1997), "The Impact of the Return on the Estimation of Systematic Risk”, Pacific-Basin Finance Journal, 5, pp. 356-376.

Brealey, R. A. and S. C. Myers (2003), "Principles of Corporate Finance," $7^{\text {th }}$ ed., New York, McGraw-Hill.

Brealey, R. A., S. C. Myers, and F. Allen (2005), "Principles of Corporate Finance," $8^{\text {th }}$ ed., McGraw-Hill/Irwin.

Brennan, M. J. and F. Li (2008), “Agency and Asset Pricing," UCLA Working Paper, Ssrn n. 1104546.

Brigham, E. and P. R. Daves (2007), "Intermediate Financial Management," $9^{\text {th }}$ ed., Thomson OneNE.

Brigham, E. and L. C. Gapenski (1977), "Financial Management: Theory and Practice," Dryden Press.

Brigham, E. and J. F. Houston (2007), "Fundamentals of Financial Management," $11^{\text {th }}$ ed., Thomson One.

Broquet, C., R. Cobbaut, R. Gillet, and A. van den Bergh (2004), “Gestion de portefeuille," $4^{\text {th }}$ ed., De Boeck.

Brown, S. J., W. N. Goetzmann, and S. A. Ross (1995), “Survival," The Journal of Finance, July, pp. 853-873.

Brown, S. J. and J. B. Warner (1985), "Using daily stock returns: The case of event studies," Journal of Financial Economics, 14 (1), pp. 3-31.

Bruner, R. F. (1999), “Instructor's Resource Manual to accompany Case Studies in Finance,” $3^{\text {rd }}$ ed., McGraw-Hill/Irwin.

Bruner, R. F. (2004), “Applied Mergers and Acquisitions,” John Wiley and Sons, N.Y. 
Bruner, R. F., K. Eades, R. Harris, and R. Higgins (1998), "Best Practices in Estimating the Cost of Capital: Survey and Synthesis," Financial Practice and Education, Vol. 8 (1), pp. 13-28.

Buss, A. and G. Vilkov (2009), "Option-Implied Correlation and Factor Betas Revisited," SSRN WP no. 1301437.

Campbell, J. Y. and J. Mei (1993), "Where Do Betas Come From? Asset Price Dynamics and the Sources of Systematic Risk,” Review of Financial Studies, 6, pp. 567-592.

Campbell, J. Y. and T. Vuolteenaho (2004), "Bad Beta, Good Beta," American Economic Review, 94, pp. 1249-1275.

Campbell, J. Y. and Y. Nosbusch (2007), "Intergenerational Risksharing and Equilibrium Asset Prices," Journal of Monetary Economics, 54, pp. 2251-2268.

Carhart, M. M. (1997), “On persistence in mutual fund performance," Journal of Finance, 52, pp. 57-82.

Chrissos, J. and R. Gillet (2008), “Décision d'investissement," Collection Gestion Appliquée, $2^{\text {nd }}$ ed., Pearson, Paris.

Christoffersen, P., K. Jacobs, and G. Vainberg (2006), "Forward-Looking Betas,” Working Paper, Faculty of Management, McGill University.

Chung, Y. P., H. Johnson, and M. J. Schill (2001), "Asset Pricing When Returns Are Nonnormal: Fama-French Factors vs. Higher-Order Systematic Co-Moments,” SSRN no. 270233.

Claus, J. J. and J. K. Thomas (1999), “The Equity Risk Premium Is Much Lower Than You Think It Is: Empirical Estimates From A New Approach,” Research paper, Columbia Business School.

Cochrane, J. (2005), “Asset Pricing,” Princeton University Press.

Cohen, K., G. A. Hawawini, S. F. Maier, R. A. Schwartz, and D. K. Withcomb (1980), "Implications of Microstructure Theory for Empirical Research on Stock Price Behavior," Journal of Finance, 35, pp. 249-257.

Cohen, K., G. A. Hawawini, S. F. Maier, R. A. Schwartz, and D. K. Withcomb (1983), "Friction in the Trading Process and the Estimation of Systematic Risk," Journal of Financial Economics, 12, pp. 263-278.

Comer, G., N. Larrymore, and J. Rodriguez (2009), "Controlling for fixed income exposure in portfolio evaluation: Evidence from hybrid mutual funds," Review of Financial Studies, 22, pp. 481-507.

Constantinides, G. (1982), "Intertemporal Asset Pricing with Heterogeneous Consumers and Without Demand Aggregation,” Journal of Business, Vol. 55, pp. 253-267.

Copeland, T., F. Weston, and K. Shastri (2005), "Financial Theory and Corporate Policy," $4^{\text {th }}$ ed., Pearson Addison-Wesley.

Copeland, T., T. Koller, and J. Murrin (2000), "Valuation: Measuring and Managing the Value of Companies," $3^{\text {rd }}$ ed., John Wiley and Sons, N.Y.

Cremers, M. (2001), "Reviving Beta? Bayesian Tests of the CAPM when the Market Portfolio is Unobservable," Stern Working Paper. 
Cunningham, L. A. (2001), "How to Think Like Benjamin Graham and Invest Like Warren Buffett,” McGraw-Hill Publishing, New York, N.Y.

Da, Z., R. Guo, and R. Jagannathan (2009), "CAPM for Estimating the Cost of Equity Capital: Interpreting the Empirical Evidence,” NBER Working Paper No. 14889.

Damodaran, A. (2001), “The Dark Side of Valuation,” New York, Prentice-Hall.

Damodaran, A. (2005), “Applied Corporate Finance: A User's Manual,” John Wiley and Sons, $2^{\text {nd }}$ ed., N.Y.

Damodaran, A. (2006), “Damodaran on Valuation,” $2^{\text {nd }}$ ed., John Wiley and Sons, N.Y., 1994.

Danthine, J. P. and J. B. Donaldson (2001), “Intermediate Financial Theory,” Prentice-Hall.

Daveni, R. A and A. Y. Ilinitch (1992), "Complex patterns of vertical integration in the forest products industry - systematic and bankruptcy risks," Academy of Management Journal, 35 (3): pp. 596-625.

Derrig, R .A. and E. D. Orr (2004), “Equity Risk Premium: Expectations Great and Small," North American Actuarial Journal, 8 (1), pp. 45-69.

Dimson, E. (1979), “Risk Measurement when Shares are Subject to Infrequent Trading," Journal of Financial Economics, 7, pp. 197-226.

Dimson, E., P. Marsh, and M. Staunton (2006b), "DMS Global Returns data module," Chicago, Ibbotson Associates.

Dimson, E., P. Marsh, and M. Staunton (2002), "Triumph of the optimists: 101 years of global investment returns," Princeton University Press.

Duffie, J. (2001), “Dynamic Asset Pricing Theory,” $3^{\text {rd }}$ ed., Princeton University Press.

Eiteman, D. K., A. I. Stonehill, and M. H. Moffett (2006), $11^{\text {th }}$ ed., "Multinational Business Finance," Addison Wesley.

Elsas, R., M. El-Shaer, and E. Theissen (2000), "Beta and Returns Revisited: Evidence from the German Stock Market," SSRN no. 199428.

Elton, E. J., M. J. Gruber, S. J. Brown, and W. N. Goetzmann (2006), "Modern Portfolio Theory and Investment Analysis," $7^{\text {th }}$ ed., John Wiley and Sons, N.Y.

Fabozzi, F. J. and J. C. Francis (1977), "Stability tests for alphas and betas over bull and bear market conditions,” The Journal of Finance, 32 (4), pp. 1093-1128.

Fama, E. (1970), “The Behavior of Stock Market Prices,” Journal of Business, 38, pp. 34-105.

Fama, E. (1976), “Foundations of Finance,” Basic Books Inc., New York.

Fama, E. and K. French (1992), "The Cross-Section of Expected Stock Returns," Journal of Finance, 47, pp. 427-466.

Fama, E. and K. French (1996), "The CAPM is Wanted, Dead or Alive," Journal of Finance, 51, pp. 1947-1958. 
Fama, E. and K. French (2004), "The Capital Asset Pricing Model: Theory and Evidence," Journal of Economic Perspectives, 18 (Summer), pp. 25-46.

Fernández, P. (2002), "Valuation Methods and Shareholder Value Creation," Academic Press, San Diego, CA.

Fernández, P. (2004a), “Are Calculated Betas Worth for Anything?,” SSRN n. 504565.

Fernández, P. (2004b), “On the Instability of Betas: The Case of Spain,” SSRN n. 510146.

Fernández, P. (2009), "Market Risk Premium used in 2008 by Professors: a Survey with 1,400 Answers," SSRN n. 1344209.

Fernández, P. and V. Bermejo (2009), " $\beta=1$ does a better job than calculated betas," SSRN n. 1406923.

Furman, E. and R. Zitikis (2009), "General Stein-type decompositions of covariances and the CAPM,” SSRN n. 1103333.

Genton, M. and E. Ronchetti (2008), "Robust Prediction of Beta", in "Computational Methods in Financial Engineering,” eds. E. J. Kontoghiorghes, B. Rustem, and P. Winker, Springer, Berlin, pp. 147-161.

Gibbons, M. (1982), "Multivariate Tests of Financial Models: A New Approach," Journal of Financial Economics, 10, pp. 3-28.

Gitman, L. (2008), “Principles of Managerial Finance,” $5^{\text {th }}$ ed., Addison Wesley.

Glassman, J. K. and K. A. Hassett (2000), “Dow 36,000: The new strategy for profiting from the coming rise in the stock market," Three Rivers.

Gooding, A. R. and T. P. O'Malley (1977), "Market phase and the stationarity of beta," Journal of Financial and Quantitative Analysis, Dec., pp. 833-857.

Grabowski, R. J. (2009), "Problems with Cost of Capital Estimation in the Current Environment”, Update1.

Graham, J. R. and C. R. Harvey (2007), ”The Equity Risk Premium in January 2007: Evidence from the Global CFO Outlook Survey," Icfai Journal of Financial Risk Management, Vol. IV, No. 2, pp. 46-61.

Griffin, J. M. (2002), “Are the Fama and French Factors Global or Country-Specific?,” Review of Financial Studies, forthcoming.

Grinblatt, M. and S. Titman (2001), "Financial Markets \& Corporate Strategy," $2^{\text {nd }}$ ed., McGrawHill/Irwin.

Hamada, R. S. (1972), "The effect of the firm's capital structure on the systematic risk of common stocks," Journal of Finance, 27, pp. 435-452

Handa, P., S. P. Kothari, and C. Wasley (1989), "The Relation between the Return Interval and Betas: Implications for the Size Effect," Journal of Financial Economics, 23, pp. 79-100. 
Hawawini, G. A. (1980), "Intertemporal Cross Dependence in Securities Daily Returns and the Short-run Intervalling Effect on Systematic Risk," Journal of Financial and Quantitative Analysis, 15, pp. 139-149.

Hawawini, G. (1983), "Why Beta Shifts as the Return Interval Changes," Financial Analysts Journal, May-June, pp. 73-77.

Higgins, R. (2009), “Analysis for Financial Management,” $9^{\text {th }}$ ed., McGraw Hill Higher Education.

Hirshey, J. and M. Pappas (1990), “Managerial Economics,” Thomson Learning.

Howard, M. (2008), “Accounting and Business Valuation Methods,” Elsevier.

Huang, C. F. and R. Litzemberger (1988), "Foundations for Financial Economics," North-Holland.

Hull, J. (2009), “Risk Management and Financial Institutions,” $2^{\text {nd }}$ ed., Prentice Hall.

Ibbotson, R. G., "Beta Book," Ibbotson Associates, Chicago.

Jensen, M. (1968), "The performance of mutual funds in the period 1945-1964," Journal of Finance, 23 (2), pp. 389-416.

Jordan, B. and T. Miller (2006), "Fundamentals of Investments," $4^{\text {th }}$ ed., McGraw-Hill/Irwin.

Kahn, R. and R. Grinold (1999), “Active Portfolio Management,” $2^{\text {nd }}$ ed., McGraw-Hill.

Kaplan, S. and G. Andrade (1998), "How Costly is Financial (not Economic) Distress? Evidence from Highly Leveraged Transactions that Became Distressed," Journal of Finance, 53, pp. 1443-1494.

Keim, D. B. (1983), "Size Related Anomalies and Stock Return Seasonality: Further Empirical Evidence," Journal of Financial Economics, 12, pp. 13-32.

Keim, D. B. (1985), "Dividend Yields and Stock Returns: Implications of Abnormal January Returns," Journal of Financial Economics, 14, pp. 473-489.

Keown, A., W. Petty, J. Martin, and D. Scott (2006), "Foundations of Finance: The Logic and Practice of Finance Management," $5^{\text {th }}$ ed., Prentice Hall.

Kogan, L., J. Gomes, and L. Zhang (2003), "Equilibrium Cross-Section of Returns," Journal of Political Economy, 111, pp. 693-732.

Koller, T., Goedhart, M., and D. Wessels (2005), "Valuation: Measuring and Managing the Value of Companies," $4^{\text {th }}$ Ed., McKinsey \& Company, Inc. Wiley.

Kothary, S. P. and J. Shanken (1995), "In defense of Beta," Journal of Applied Corporate Finance, 8, pp. 53-58.

Kothary, S. P. and J. Shanken (1999), "Beta and Book-to-Market: Is the Glass Half Full or Half Empty?," Simon School of Business Working Paper FR 97-20.

Kothary, S. P., J. Shanken, and R. G. Sloan (1995), "Another look at the Cross-section of Expected Stock Returns," Journal of Finance, 50, pp. 185-224.

Koutmos, G. and J. Knif (2002), "Estimating Systematic Risk Using Time Varying Distributions," European Financial Management, 8, No. 1, pp. 59-73. 
Lakonishok, J. and A. Shapiro (1984), "Stock Returns, Beta, Variance and Size: An Empirical Analysis," Financial Analysts Journal, 40, pp. 36-41.

Lakonishok, J. and A. Shapiro (1986), "Systematic Risk, Total Risk and Size as Determinants of Stock Market Returns,” Journal of Banking and Finance ,10, pp. 115-132.

Lakonishok, J., A. Shleifer, and R. W. Vishny (1994), "Contrarian investment, Extrapolation, and Risk," Journal of Finance ,49, pp. 1541-1578.

Lee S. B. and D. J. Kim (1997), "Price Limits and Beta," Review of Quantitative Finance and Accounting, 9, pp. 35-52.

Levy, H. (1998), “Principles of Corporate Finance,” South-Western Educational Publishing.

Levy, H. (1984), "Measuring risk and performance over alternative investment horizons," Financial Analysts Journal, 40 (2), pp. 61-68.

Lintner, J. (1965), "The Valuation of Risk Assets and the Selection of Risky Investments in Stock Portfolios and Capital Budgets," Review of Economics and Statistics, Vol. 47, pp. 13-37.

Lintner, J. (1969), “The Aggregation of Investor's Diverse Judgments and Preferences in Purely Competitive Security Markets," Journal of Financial and Quantitative Analysis, December, pp. 347-400.

Litzenberger, R. H and K. Ramaswamy (1979), "The Effects of Personal Taxes and Dividends on Capital Asset Prices: Theory and Empirical Evidence," Journal of Financial Economics, 7, pp. 163-195.

Lobe, S., T. Niermeier, W. Essler, and K. Roder (2008), "Do Managers follow the Shareholder Value Principle when applying Capital Budgeting Methods?,” SSRN N. 1089379.

Los, C. A. (2000), “Computational Finance,” World Scientific Publishing Co.

Los, C. A. (2003), “Financial Market Risk: Measurement \& Analysis,” $2^{\text {nd }}$ ed., Routledge.

Mamaysky, H., M. Spiegel, and H. Zhang (2007), "Improved Forecasting of Mutual Fund Alphas and Betas," Review of Finance, 11, pp. 359-400.

Mandelker, G. N. and S. G. Rhee (1984), "The Impact of the Degrees of Operating and Financial Leverage on Systematic Risk of Common Stock," Journal of Financial and Quantitative Analysis, 19 (1), pp. 45-57.

Marin, J. M. and G. Rubio (2001), “Economía Financiera,” Antoni Bosch, editor.

Markowitz, Harry (1952), “Portfolio Selection”, Journal of Finance, 7, 1, pp. 77-99.

Markowitz, Harry M. (2005), "Market Efficiency: A Theoretical Distinction \& So What?," Working Paper.

Markowitz, Harry (1959), "Portfolio Selection: Efficient Diversification of Investments," Cowles Foundation Monograph, No. 16, John Wiley and Sons, N.Y.

Mascarenas, J. (2005), “Fusiones y Adquisiciones de Empresas,” 4th ed., McGraw Hill, Madrid. 
Mas-Colell, A., M. D. Whinston, and J. R. Green (1995), “Microeconomic Theory,” Oxford University Press.

Mossin, J. (1966), “Equilibrium in a Capital Asset Market,” Econometrica, Vol. 34, pp. 768-783.

Murphy, A. (2000), “Scientific Investment Analysis,” $2^{\text {nd }}$ ed., Quorum Books.

Nagel, G. L., D. R. Peterson, and R. Pratti (2007), "The Effect of Risk Factors on Estimating the Cost of Equity," Quarterly Journal of Business and Economics (Finance and Accounting) Vol. 46 No 1.

Palepu, K. G. and P. M. Healy (2007), "Business Analysis and Valuation: Using Financial Statements,” 4 ed., South-Western College Pub.

Pereiro, L. E. (2002), "Valuation of Companies in Emerging Markets," $1^{\text {st }}$ ed., John Wiley and Sons, N.Y.

Pettengill, G. N., Sundaram, S., and I. Mathur (1995), "The Conditional Relation Between Beta and Returns," Journal of Financial and Quantitative Analysis, 30, No. 1, pp. 101-116.

Pike, R. and B. Neale (2003), “Corporate Finance \& Investment: Decisions \& Strategies," $4^{\text {th }}$ ed., Financial Times Management, Pearson,

Reilly, F. K. and K. C. Brown (2002), "Investment Analysis and Portfolio Management," $7^{\text {th }}$ ed., South-Western Coll. Pub.

Reilly, F. K. and D. J. Wright (1988), “A comparison of published betas," The Journal of Portfolio Management, Spring, pp. 64-69.

Reilly, F. K., D. J. Wright, and K. C. Chan (2000), "Bond Market Volatility Compared to Stock Market Volatility,” Journal of Portfolio Management, (Fall), pp. 82-92.

Reinganum, M. R. (1981), "Misspecification of Capital Asset Pricing: Empirical Anomalies Based on Earnings Yields and Market Values," Journal of Financial Economics, March, pp. 19-46.

Reinhart, W. J., "Portfolio Management: Theory, Behavioral Aspects and Applications.”

Rohini, S. (2008a), "Beta Estimation in the Indian Stock Market: Stability, Stationarity and Computational Considerations," Decision (IIM Calcutta), 35 (2).

Rohini, S. (2008b), "Beta Stationarity over Bull and Bear Markets in India," ICFAI Journal of Applied Finance, 14 (4), pp. 32-47.

Rojo, A. (2007), "Valoración de empresas y gestión basada en valor," Editorial Thompson Paraninfo.

Roll, R. (1977), “A Critique of the Asset Pricing Theory's Tests," Journal of Financial Economics, March, pp. 129-176.

Roll, R. (1981), “A Possible Explanation of the Small Firm Effect," Journal of Finance, 36, pp. 879-888.

Roll, R. and S. A. Ross (1994), "On the Cross-Sectional Relation between Expected Returns and Betas,” Journal of Finance, 49, pp. 101-121. 
Ross, S. A., R. W. Westerfield, and J. F. Jaffe (2005), “Corporate Finance," $7^{\text {th }}$ ed., Homewood, IL: McGraw-Hill/Irwin.

Ross, S. A., R. W. Westerfield, and J. F. Jaffe (1993), “Corporate Finance.” $3^{\text {rd }}$ ed., Homewood, IL: Irwin/McGraw-Hill.

Scholes, M. and J. Williams (1977), "Estimating Betas from Nonsynchronous Data," Journal of Financial Economics, 5, pp. 309-327.

Shalit, H. and S. Yitzhaki (2002), "Estimating Beta," Review of Quantitative Finance and Accounting, 18 (2).

Shanken, J. (1992), "On the Estimation of Beta-Pricing Models," The Review of Financial Studies, 5, No. 1, pp. 1-33.

Shapiro, A. C. (2005), "Capital Budgeting and Investment Analysis," Pearson, Prentice Hall.

Sharpe, W. (1964), "Capital Asset Prices: A Theory of Capital Market Equilibrium under Conditions of Risk," Journal of Finance, Vol. 19, pp. 425-442.

Shenoy, C. and K. McCarthy (2008), "Applied Portfolio Management: How University of Kansas Students Generate Alpha to Beat the Street,” Wiley Finance.

Shirreff, D. (2004), “Dealing with Financial Risk,” The Economist.

Smith, K. V. (1978), "The Effect of Intervalling on Estimating Parameters of Capital Asset Pricing Model," Journal of Financial and Quantitative Analysis, 13, pp. 313-332.

Smith, R. L. and J. Kiholm-Smith (2003), “Entrepreneurial Finance,” $2^{\text {nd }}$ ed., John Wiley and Sons, N.Y.

Statman, M. (1981), “Betas compared: Merrill Lynch vs. Value Line," Journal of Portfolio Management, (Winter), pp. 41-44.

Tinic, S. M. and R. West (1984), "Risk and Return, January vs. the Rest of the Year," Journal of Financial Economics, 13 (4), pp. 561-574.

Tole, T. M. (1981), "How to maximize stationarity of beta," The Journal of Portfolio Management, (Winter), pp. 45-49.

Treynor, J. (1965), "How to rate management of investment funds," Harvard Business Review, 43, Jan.-Feb., pp. 63-75.

Turner, T. (2005), "Short Term trading in the New Stock Market," St. Martin’s Griffin.

Vasicek, O. A. (1973), "A note on using cross-sectional information in Bayesean estimation of security betas," The Journal of Finance, 28 (5), pp. 1233-1239.

Womack, K. L. and Y. Zhang (2003),"Understanding Risk and Return, the CAPM, and the FamaFrench Three-Factor Model," Tuck Case No. 03-111, SSRN n. 481881. 


\section{Comments on the paper}

1. Most of us use the CAPM framework as a precisely that - a framework for us to teach to and for students to think within. It is much like any historic cost Balance Sheet in that regard - the values are out of date - but it does represent a starting point for the valuation debate.

2. Don't forget that we continue to use beta in part because industry continues to use it as well, warts and all. (If you like someone "warts and all," you like them with all their faults).

3. Based on the survey I remember, this goes way beyond the data you collected, at least in my frail memory and based on the survey I remember taking. I certainly teach beta - it's a useful way to look at risk. I also teach other things, including looking at the relative risk of investments and their cash flows. And for many investors, beta is not a useful construct if we are looking at a portfolio that does not meet its basic constructs - in particular one dealing with diversification. If the basic tenets of the beta model (or a multiple factor model) are met, that's a pretty good way to judge risk, it seems to me. Those tenets are not met by many portfolios, including the "portfolio" that occurs within a company as it judges projects. I think your paragraph is inflammatory without adding a great deal to your argument.

Yes. Inflammatory may be too harsh a word, but it certainly is controversial - it's going to upset some folks who see it as overreaching at least. I think the first part of it is just fine- - it appropriately suggests that we, as a profession, teach people to consider investment cash flow appropriately. The second half then indicts the profession (most professors, it says) by suggesting that we "teach them to use a discount rate using two factors." We certainly do that. What the statement does not say is that we do not do that exclusively when we look at cost of capital. We also teach students the assumptions around those discount factors, and the frailties of them, and things to do when those assumptions are not met. It is the frailties that allow us to see when a tool is useful and when it is not - chisels are marvelous tools, but probably are not appropriate for use as screwdrivers. I think beta, properly applied in the proper circumstances, is a marvelous tool. But not in all circumstances. I think the final sentence fails to recognize that there are other parts to the class than the two factor model.

Well done. Your results support my contention in my Galton's Error article (which is a good reference to include in your survey in case you submit it to a journal for publication: Cornelis A. Los, "Galton's Error and the Under-Representation of Systematic Risk," Journal of Banking and Finance, Vol. 23, No. 12, December, 1999, pp. 1793-1829. See also my paper to be presented at the European Financial Management Association (EFMA) in Milan, Italy, June 24-27, 2009 (Hope to see you there!), "Investment Model Uncertainty and Fair Pricing."

I have glanced through your paper. The insights are very interesting and timely because I will teach a class this week on estimating betas for use in the CAPM. We will, of course, ask if the betas make economic sense and do a sensitivity analysis to see how far wrong the beta estimates could without changing the decision we would make.

Thank you very much for letting me know that the paper has been uploaded on sstn. I have gone through the paper and I found very useful to know how other academics approach issues which are common to all of us. I am looking forward to the version with the answers from people from the industry, which may add a new prespective to the subject.

Thanks. Although I did not read everything, I am able to say: what a magnificent job!

Congratulations on another interesting paper. It looks like confusion reigns!

Creo que lo que enseñan los profesores es relevante para que los alumnos sepan una aproximación teórica a los problemas, en particular cálculo de CF, betas... en la práctica esto es irrelevante, porque si la empresa es de ellos hacen lo que quieren, y si no es de ellos - trabajan para alguien - tienen que hacer lo que es conveniente 
para el que paga dentro de lo razonable y explicable (para este último punto es importante saber al menos la teoría).

No me explico cómo ante tanta evidencia acerca de la peligrosidad e (muchas veces) inutilidad de las betas calculadas aún se siguen usando profusamente. Por cierto, me parecen muy interesantes las aproximaciones "cualitativas" al cálculo de las betas (las del capítulo 6 de tu artículo). Pero al final no sé si es mejor que simplemente estimar "a pelo" una prima sobre la rentabilidad sin riego, de acuerdo con lo que parezca razonable para la compañía.

Me parece demasiado bajo el porcentaje de gente que utiliza el juicio experto (0,9\%). Lo normal es que, si no te fías mucho de los métodos utilizados, complementes y matices el resultado con algún juicio personal subjetivo. Es como si nadie quisiese reconocer que utiliza el juicio experto porque no es académico pero en realidad lo utiliza. La razón podría ser que nos encontramos en un momento en que todo el mundo es muy sensible a la utilización de "juicios expertos" en cualquier ámbito. Nos encontramos en un entorno económico muy complicado, sin muchas recetas para afrontarlo, en el que parece claro que nos abocamos a un nuevo "modelo de negocio" donde hay que acometer reformas estructurales de gran calado (como la reinvención del sistema financiero, donde sólo se habla de "come back to the basics"). Este hecho produce que exista la sensación en el mercado de que todas las valoraciones de compañias y negocios que se han hecho en los últimos años están sobrevaloradas. Sólo se habla de "sobrecapacidad y redimensionamiento de las entidades financieras" y que muchas empresas no van a poder salir de esta crisis por la compra de empresas con elevada deuda que se han realizado en los últimos años. Al igual que ocurre cuando analizas una empresa o quieres calificarla con un rating determinado, si no te fías de la fuente de obtención del dato es necesario "corregir" el resultado de forma manual porque, en muchas ocasiones, si se utilizan técnicas estadísticas basadas en simulaciones históricas, éstas no recogen todos los datos subjetivos (por ejemplo, capacidad de gestión, expertise de los gestores, etc.) o están basados en un pasado que no es "extrapolable”. La utilización de simulaciones Montecarlo para ver la evolución de las variables en el futuro podría permitir estimar escenarios que no han ocurrido en el pasado, pero presenta muchas dificultades para su estimación de correlaciones así como para la interpretación de resultados.

En nuestro caso, como la mayoría de nuestras inversiones son en títulos no líquidos, usamos betas de comparativos en otros países, y los ajustamos según sea el caso. Ahora, estas betas las usamos a su vez como punto de comparación, como se dice en inglés: un sanity check.

I really do appreciate your work. I was wondering if you are going to the 2009 Financial Management Conference in Reno, Nevada, United States. It is October 21-24. I organize and chair a round table that this survey research as well as your other survey research would be great for. If you were going to be there, I would like to invite you to present this.

Después de unos años trabajando en valoración de empresas, intento dedicar el mayor tiempo posible a la estimación de cash flows. Posteriormente, intento utilizar el "common sense" en la tasa de descuento. La verdad es que nuestro banco utiliza el CAPM (yo no creo demasiado, quizás influido por mis clases de IESE) y hay una tasa fija de riesgo y de prima de mercado de la casa. Yo intento ajustar otras magnitudes, como beta o coste de la deuda de la empresa, para utilizar una tasa de descuento que tenga sentido para mí. Al final busco que esa tasa de descuento tenga sentido con la situación de mercado y con mi estimación de riesgo percibido de cada empresa. Por ejemplo, en el sector que cubro de eléctricas, en una situación de sobrecapacidad y de elevado endeudamiento, no sé si tiene mucho sentido que las empresas sigan invirtiendo, y esto me hace ajustar la tasa de descuento que utilizo.

Sobre la encuesta de los betas mis comentarios son los siguientes:

1. El ser humano se siente muy incómodo cuando no puede medir.

2. Medir el riesgo es complicado porque tiene variables extrínsecas (propias del mercado, del proyecto, etc.), pero también intrínsecas (propias de cada individuo, que además son cambiantes en el tiempo para cada individuo). 
3. Por lo anterior, me resulta prácticamente imposible creer que toda la complejidad externa, pero más aún la complejidad interna del ser humano, pueda ser sintetizada en una fórmula simple.

4. Por anterior, las frustraciones y decepciones del uso de herramientas como los betas provienen de exigirles más de lo que pueden dar.

5. Por tanto, tanto los académicos como aquellos que trabajan con estas herramientas son responsables en el uso de éstas en cuanto a destacar con fuerza sus serias limitaciones y, por ende, el cuidado máximo que se debe tener al usarlas como herramientas en toma de decisiones.

6. Como conclusión, no me extraña la masiva frustración que muestra el survey en cuanto al uso de betas, pero me llama muchísimo la atención el alto número que aún las utiliza a pesar de reconocer las grandes limitaciones que tiene. Y más aún, el uso como única y absoluta herramienta en vez de complementarla con sentido común y otras herramientas de aproximación en la medición del riesgo.

Quizá la explicación está en precisamente la fuerte aversión, por no decir tolerancia cero, al riesgo a equivocarse, a fracasar. De este modo la beta se convierte en, perdonando la expresión, un CYA (cover your ass) cuando evalúas proyectos de inversión.

Financial valuation of assets is not the same as the theory of business valuation. Since the distinction of these two disciplines is blurred many issues arise. The reason is the imperialism in economics and the overwhelming importance of the neoclassical based concepts such as CAPM or MM. There may be markets for listed shares with dispersed ownership but there are virtually no continuously existing markets for whole businesses. The ownership rights are traded differently and the equilibrium price is created differently, which means during the factual negotiations. The result is that the CAPM, etc., theory can hardly provide relevant outcomes.

Since my education is American too, I know that there is virtually no knowledge about the traditional European concepts of and approaches to business valuation there - such as, in synthesis, Matschke, Brsel, 2007; Hering, 2006; Olbrich, 2002, and others. This is also obvious from the valuable survey in your research.

Do you know what I learned in my MBA advanced finance and valuation course? DCF models and the application of those. The professors just pointed that this was what we were supposed to apply! Since DCFs are based on CAPM and MM, I raised a question how can this work since their fundamentals CAPM and MM are based on other assumptions, such as different treatment of taxes, different planning horizons, or existence of preferences. It only brought raising eyebrows: "Everyone is using this - so what?"

The equilibrium financial theory is a misleading generalization of reality which is not very useful for the real world transactions. The theory of business valuation is nailed on the European world of private equity markets where the price is not externally given and the assets being traded are not standardized. Not only in the theory of business valuation but also in the International Valuation Standards or the German IDW standards for business valuations there is a clear principle according to which all business valuations should be done: there is nothing like intrinsic value or general equilibrium value in the real world, there are only basis of values establishing a clear link between the purpose of the valuation assignment and the applicability of the value estimated.

Crucially important is the fact that the standards of professional valuers are not based on the theory of financial valuation but rather on the evolutionary developed "best rules of conduct."

In your paper you have included various criticisms on the beta though what I am missing is the perspective of the real use of the results: when and why do we need the betas? Who does care about estimating a hypothetical neoclassical equilibrium price? Should the term intrinsic value be used in real business valuations? The professors are maybe interested in these estimates but do the users really care? Do they need these kind of estimates? How about the behavioral driving factors and their impact in public and private equity markets? Here in Europe the private equity markets are truly incomparable to the United States public ones and the normative valuation standards are needed in order to clear up the nature of the real world transaction... though not on theoretical but on best practice basis. 